\title{
CLIMATIC CYCLES AS SEDIMENTARY CONTROLS OF RIFT-BASIN LACUSTRINE DEPOSITS IN THE \\ EARLY MESOZOIC NEWARK BASIN BASED ON CONTINUOUS CORE
}

\author{
JOSEPH P. SMOOT AND PAUL E. OLSEN \\ U.S. Geological Survey, M.S.939, Denver Federal Center, Denver, CO 80225; \\ and Lamont-Doherty Geological Observatory, Palisades, NY 10964
}

\begin{abstract}
The Newark Basin Coring Project (NBCP) has recovered over $6730 \mathrm{~m}$ of con-tinuous core from 7 coring sites. Cores spanning the $4800 \mathrm{~m}$ of Lockatong and Passaic formations are characterized by cyclic lacustrine mudstone and shale, which reflect rise and fall of lake level in response to climatic fluctuations at intervals of 20,000 years and larger patterns of 100,000and 400,000-year intervals. Sedimentary structures in the mudstones include:
\end{abstract}

1. Organic-rich laminites with thin, flat, continuous lamination; thick lamination with diffuse or irregular boundaries; silty or sandy laminae; or crystal-rich lamination.

2. Mudcracked, thin-bedded mudstone with lenticular sandstone layers; graded sandstone layers; mudstone layers with sharp contacts; muddy siltstone curls; or crystal-rich layers.

3. Massive mudstones with angular breccia fabric; vesicular fabric; rounded breccia fabric; root-disrupted fabric; or crystal-rich fabrics.

These structures define five types of cycles:

1. Cycles dominated by thick, organic-rich laminites deposited in deep lakes and rounded breccias, reflecting deflated, salt-encrusted mudflats.

2. Cycles similar to the previous, but with more thin-bedded mudstone and massive mudstone with upward-fining crystal sequences reflecting saline mudflats.

3. Cycles with mudcracked thin beds grading to brecciated mudstone, then vesicular fabric reflecting shallow lakes drying up to dry playa mudflats.

4. Cycles similar to the previous, but with more organic-rich laminites or thin beds and rootdisrupted mudstone at top, indicating wetter conditions and vegetation growth before lake transgressions.

5. Cycles dominated by root-disrupted mudstone and thin, organic-poor laminites or thin beds reflecting thick soils superimposed on shallow lake deposits.

The abundance of each cycle type changes through the stratigraphic section, reflecting the change from arid conditions in a narrow basin upward to semi-arid to subhumid conditions in a 
broad basin. The use of climatic patterns and tectonic setting can provide important information toward modeling source and reservoir rocks in rift basin lacustrine deposits.

\section{INTRODUCTION}

The Newark Basin is a half-graben bounded on the northwest side by normal to oblique-normal faults and filled with late Triassic through early Jurassic fluvial and lacustrine sedimentary rocks, tholeiitic basalt flows, and diabase intrusives. The basin covers about $7500 \mathrm{~km}^{2}$ and extends from southern New York across New Jersey and into southeastern Pennsylvania (Fig. 1). The Newark Basin is one of a group of extensional basins that extend along the eastern margin of North America (Fig. 2) whose depositional fills are collectively called the Newark Supergroup (Froelich and Olsen, 1983). These basins formed during the early Mesozoic continental rifting that eventually led to the opening of the Atlantic Ocean. Newark Supergroup basins are important analogs to oil-producing basins beneath the Atlantic Shelf and are currently being assessed for their petroleum potential.

The Newark Basin is the largest and best-exposed of the Newark Supergroup basins and, therefore, is also the best studied. The faulted northwest border of the Newark Basin is reactivated Precambrian and Paleozoic faults, so the geometry reflects the trends of these older faults (Ratcliffe and Burton, 1985; Ratcliffe and others, 1986). The stratigraphy of the Newark Basin is partially repeated in three fault blocks that provide some indication of lateral facies relationships from the unconformable southeast margin to the faulted northwest margin. Evidence for synsedimentary movement of the faults of the northwest border of the Newark Basin includes thick conglomerates restricted to the fault margin that intercalate basinward with finer-grained deposits, systematic thickening of sedimentary units toward the border faults, and deformation structures that are consistent with prelithification fault movement (see Olsen and others, 1989; Smoot, 1991).

\section{Newark Basin Stratigraphy}

Sedimentary rocks of the Newark Basin rest unconformably on Precambrian and Paleozoic basement rocks. The oldest unit is the fluvial Stockton Formation of Carnian age. The Stockton is conglomeratic, braided stream deposits at the base and fine upward to meandering river sandstone and mudstone deposits. The paleocurrent indicators and provenance reflect a drainage from the southeast across the width of the basin. The Stockton thickens away from the southeast unconformable boundary with progressively thicker mudstone interbeds between braided and meandering stream deposits.

The Stockton Formation is overlain by the predominantly lacustrine Lockatong and Passaic formations. The Carnian Lockatong Formation is characterized by a predominance of black shale and gray mudstone comprising cycles 3 to $7 \mathrm{~m}$ thick. The Passaic Formation, which is upper Carnian to lowermost Hettangian in age, also consists of cyclic shale and mudstone, but differs from the Lockatong by having a greater abundance of red mudstone and sandstone. The 
Lockatong Formation grades through fluvial-deltaic sandstone and siltstone into the conglomeratic, fluvial Hammer Creek Formation to the west and into alluvial-fan conglomerates along the northwest border. The Passaic Formation lacustrine mudstones grade into fluvial-deltaic sandstone and conglomerate deposits in the northeastern part of the basin and into alluvial-fan sandstone and conglomerate along the northwest border.

The Passaic Formation is overlain by a series of tholeiitic basalts and fluvial-lacustrine sedimentary rocks that are mostly Hettangian in age. These include the Orange Mountain Basalt, Feltville Formation, Preakness Basalt, Towaco Formation, Hook Mountain Basalt, and Boonton Formation. The sedimentary formations consist of cyclic alternations of lacustrine shales and fluvial-deltaic sandstone and siltstone, all of which grade to alluvial-fan conglomerates along the northwest border. The basalt formations are each composed of several flood basalt flows (Tollo and Gottfried, 1992). The basalt flows are fed by diabase sheets and dikes that intrude and thermally metamorphose the Triassic and younger Jurassic sedimentary deposits.

The transition from fluvial to lacustrine sedimentation in the Newark Basin is attributed to its tectonic development (Smoot, 1985, 1991; Schlische and Olsen, 1990). During the initial stages of basin development, fluvial drainages were captured as high-gradient braided streams. The streams flowed across the basin and exited via outlets cut through the rising hills on the faulted margin. The outlets, however, constricted flow, and water backed up over floodplains during large floods, resulting in thick mud interbeds. The deposition of thick muds lowered the stream gradient so that fluvial style evolved into meandering rivers. The lower-gradient rivers, however, had less stream power to cut outlets as the basin continued to subside. This eventually led to closure of the outlets and closed-basin lacustrine conditions of the Lockatong and Passaic formations. Schlische and Olsen (1990) interpreted the transition from numerous thick black shales in the Lockatong to infrequent black shales in the Passaic as evidence of a decreased abundance of deep lakes. They noted that extension on a fault in a half-graben requires that the basin becomes progressively wider, and argued that more water would be needed to make a deep lake in the wider basin. Therefore, the Lockatong Formation represents early closure in a narrow basin, and the Passaic Formation represents shallow lakes in a broad basin. Schlische and Olsen (1990) further argued that the basalt formations resulted from increased extension and subsidence, leading to deeper lakes in the Feltville, Towaco, and Boonton formations.

\section{Climatic Signals}

The effects of climatic change along paleolatitude and through time are evident in the Newark Supergroup. The southernmost basins of the Newark Supergroup contain coals and lack arid depositional environments, whereas the northernmost basins contain evaporites and have abundant arid depositional environments (Hubert and Mertz, 1980, 1984; Smoot, 1991). This variation is attributed to proximity to the equator during the early Mesozoic, with the more southern basins being located in the tropical belt near the equator. Climate change through time has been cited for (a) the restriction of coal-bearing units to the Carnian (Robbins and others, 1988), (b) stratigraphic alternations of mudstones with playa fabrics in the late Carnian through Norian and in the late Hettangian (or Sinemurian?), and (c) mudstones with root and burrow fabrics in 


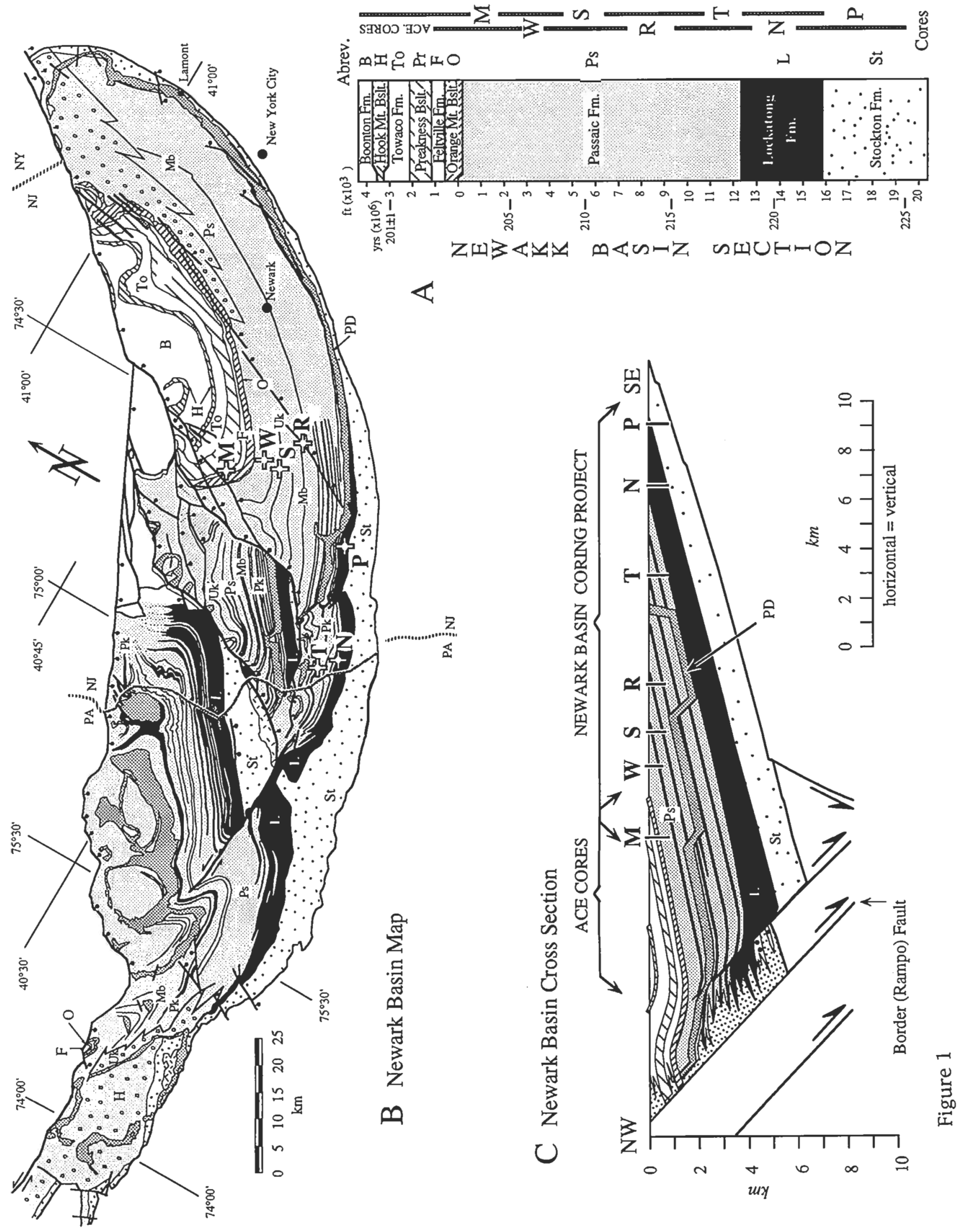


FIG. 1.-Geologic map of the Newark Basin with stratigraphic section and cross section across the central part. Core locations are M - Martinsville; W - Weston Canal; S - Somerset; R Rutgers; T - Titusville; N - Nursery Road; and P - Princeton. ACE CORES refers to a series of cores collected by the Army Corp. of Engineers in 1985-1986. Circle patterns depict fluvial deposits of the Hammer Creek Formation to the west $(\mathrm{H})$ and a fluvial facies of the Passaic Formation to the east.

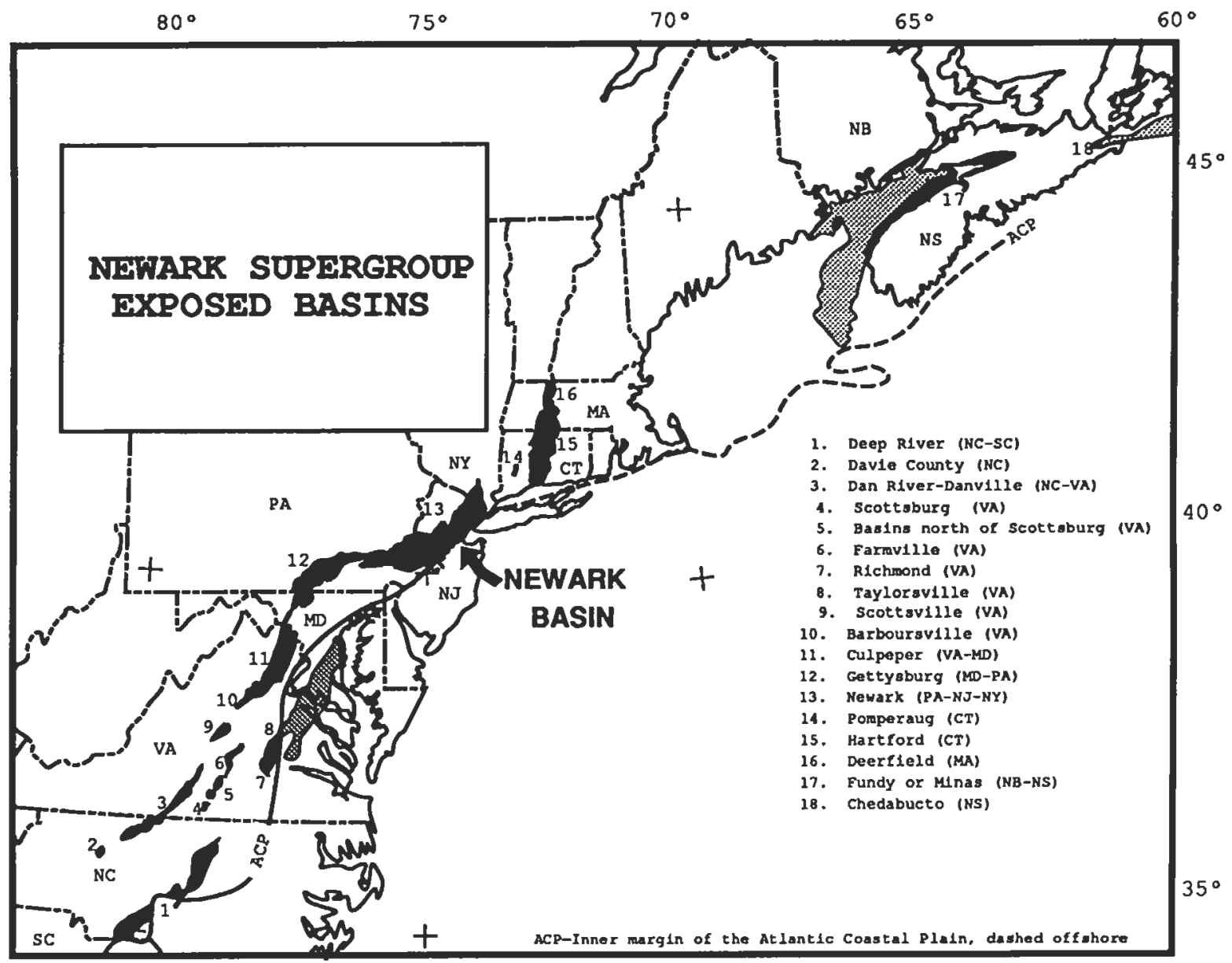

FIG. 2.-Location of exposed basins of the Newark Supergroup in eastern North America. Shaded areas are portions of basins that are covered by coastal-plain sediments. Modified from Smoot (1991). 
the early to middle Carnian and early Hettangian (Smoot and Olsen, 1988; Smoot, 1991). Smoot (1991) argued that these climate changes through time are also found in the fluvial deposits and that the relative effects of paleolatitude on the climatic fluctuations are also evident.

Cyclic lacustrine deposits are believed to be the most dramatic indicators of climatic change. Van Houten $(1962,1964)$ first described cyclic sequences of laminated shale grading to massive mudstone in the Newark Basin and attributed them to changes in the lake depth as a function of rainfall. Within each cycle (Fig. 3) the lacustrine shale grades upward into mudstone or sandstone that have subaerial exposure fabrics (Smoot and Olsen, 1988; Smoot, 1991). Olsen (1986) quantified this cyclicity for the Newark Basin and other basins in the Newark Supergroup by assigning relative water depths to degrees of layering in the lacustrine mudstones and analyzing the thickness distribution using Fourier analysis. He found that the changes in degree of layering occurred in discrete frequencies of thickness and that if a single sedimentation rate was assumed, the frequencies coincide with the Milankovitch periodicities of orbital behavior. Olsen (1986) concluded that cycles of 3- to 7-m thickness, which he termed Van Houten cycles, are comparable to 20,000-year precession cycles, and that these are grouped into compound cycles equivalent to 100,000 - and 400,000-year eccentricity cycles. If these periodicities are correct, the cyclic lacustrine deposits provide an unparalleled chronometer for examining stratigraphic, paleomagnetic, and paleontologic relationships.

Mapping of the lacustrine cycles in the Newark Basin demonstrates their lateral continuity (McLaughlin, 1946; Olsen, 1988; Olsen and others, 1989). Meter-scale layers of black and gray shale are mappable over almost the entire area of the basin. They intertongue with deltaic deposits, wave-formed sandstone and conglomerate, fluvial deposits, and alluvial-fan deposits near the basin margins, but are interbedded with subaerial mudstone over most of the basin floor. The absence of fluvial or deltaic deposits in the central basin, even during periods of subaerial exposure, is evidence of the closed-basin hydrology (Smoot, 1985). Groupings of black shales and succeeding red beds in the Lockatong and Passaic formations have been given informal and, in some cases, formal member status (Lutrell, 1989; Olsen and others, 1989).

\section{CORE RECORD OF THE LOCKATONG AND PASSAIC FORMATIONS}

The National Science Foundation-funded Newark Basin Coring Project (NBCP) has recovered over $6730 \mathrm{~m}(22,100 \mathrm{ft})$ of continuous core from 7 coring sites (Fig. 4). The cores span most of the fluvial Stockton Formation, all of the lacustrine Lockatong and Passaic formations $(4,800 \mathrm{~m} ; 16,000 \mathrm{ft})$, the Orange Mountain Basalt $(165 \mathrm{~m} ; 541 \mathrm{ft})$, and nearly all of the lacustrine Feltville Formation $(177 \mathrm{~m} ; 581 \mathrm{ft})$. The cyclic pattern of sedimentation dominates the entire thickness, but the style of sedimentation changes from the base to top. The descriptions provided here will emphasize the vertical variability within the cyclic pattern and its climatic significance.

A variety of subaqueous and subaerial depositional facies are evidenced by the sedimentary structures in the Newark cores. These will be briefly described before their relationships in cycles are discussed. 


\section{VAN HOUTEN CYCLES}

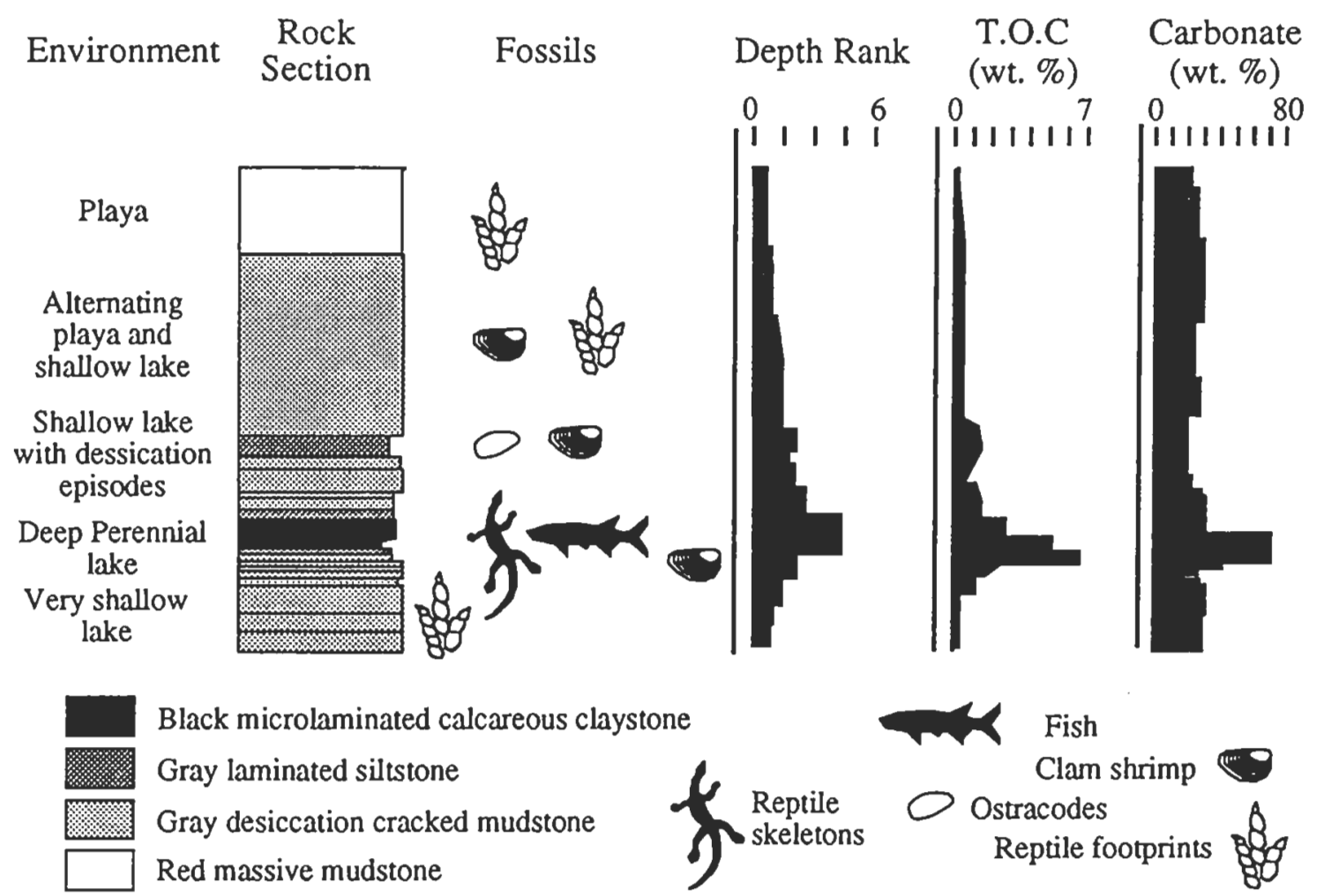

COMPOUND CYCLES

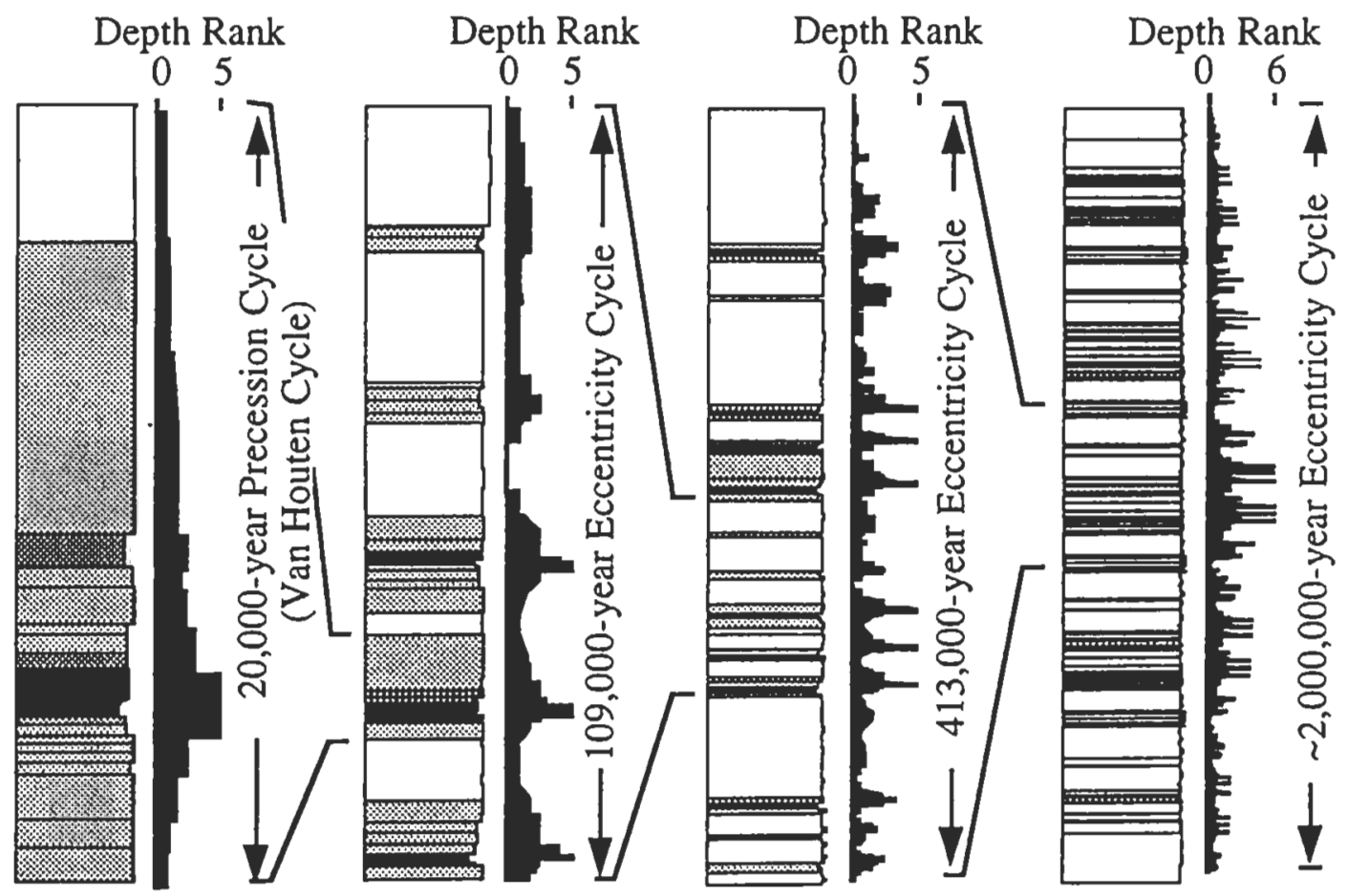

B

FIG. 3.-Hierarchy of Van Houten cycles in the Lockatong and Passaic formations. Depth rank is an arbitrary measure of the degree of layering that reflects depth of standing water in the lacustrine setting. Modified from Olsen (1986). 


\section{Black to Dark Gray, Organic-Rich Laminites}

Laminites containing as much as 8 percent organic material represent the deepest lake conditions. The laminites have a fair amount of variability in texture that is categorized as (1) thin, flat, continuous laminae; (2) thick laminae with irregular to diffuse boundaries; (3) silty or sandy laminae; and (4) laminae rich in crystal pseudomorphs. All of these types of laminites may be disrupted by soft-sediment deformation, or they may be disrupted by polygonal cracks that initiate in an overlying deposit.

Flat, continuous, thin laminae (less than $0.5 \mathrm{~mm}$ thick)(Fig. 5A) are composed of alternations of organic material and carbonate or clay. Fish bones, scales, and phosphatic coprolites are common in this type of organic-rich laminite. The laminite was deposited in deep water, well below storm-wave base and in conditions that discouraged bottom feeders.

Thick laminae (0.5-5.0 mm thick) are defined by the relative concentration of organic matter, silt, or carbonate. The boundaries between layers are either diffuse or are disrupted by ovate to circular cross sections (Fig. 5B). The disruptions are attributed to burrows that are mostly parallel to the bedding-plane surface. This was deposited in water that is below storm-wave base with enough oxygen to sustain burrowing organisms.

Siltstone and sandstone laminae in organic-rich laminites commonly thicken and thin regularly over a sharp, scalloped base (Fig. 5C). The thickness of these layers varies from $0.5 \mathrm{~mm}$-thick pinch-and-swell laminae up to isolated lenses about $2 \mathrm{~cm}$ thick. These layers are formed by waves. The thin pinch-and-swell laminae were rolling-grain ripples that represent the lowest energy wave conditions (Harms and others, 1982), whereas the thicker lenses are vortex oscillatory ripples that require higher wave energy. Another style of siltstone and sandstone layering is graded laminae that overlie scour bases with common load casts. The graded laminae may also thicken and thin or may have internal cross-stratification. These layers are probably turbidite deposits. The turbidites may have initiated from river flow into the basin or at least some of them were formed by storm-wave surges. Mudstone layers between the siltstone and sandstone layers are commonly massive and disrupted by small, randomly oriented tubes. These represent background quiescent water, where the bottom is oxygenated enough to support burrowing organisms.

Euhedral to anhedral crystals of calcite, about 0.5 to $1.0 \mathrm{~mm}$ on the long axis, are abundant in some black laminites (Fig. 5D). The euhedral crystal cross sections are nearly equant and monoclinic, which is inconsistent with calcite and suggests that they are pseudomorphs after a former evaporite mineral. The crystals are most commonly concentrated in layers similar to sandstone and siltstone, but the boundaries are more bulbous with euhedral crystal projections into the surrounding mudstone. The calcite crystals also are randomly scattered in layers a few centimeters thick. The crystals are interpreted as evaporite minerals precipitated from a saline lake mostly as cumulate crystals (Smoot and Lowenstein, 1991). They were reworked by waves into layers, which also accounts for some of the anhedral shapes due to abrasion. The bulbous character of some layers may be due to overgrowth of crystals after deposition. Crystals scattered in massive mudstone were probably intrasediment growths in brine-saturated mud. 

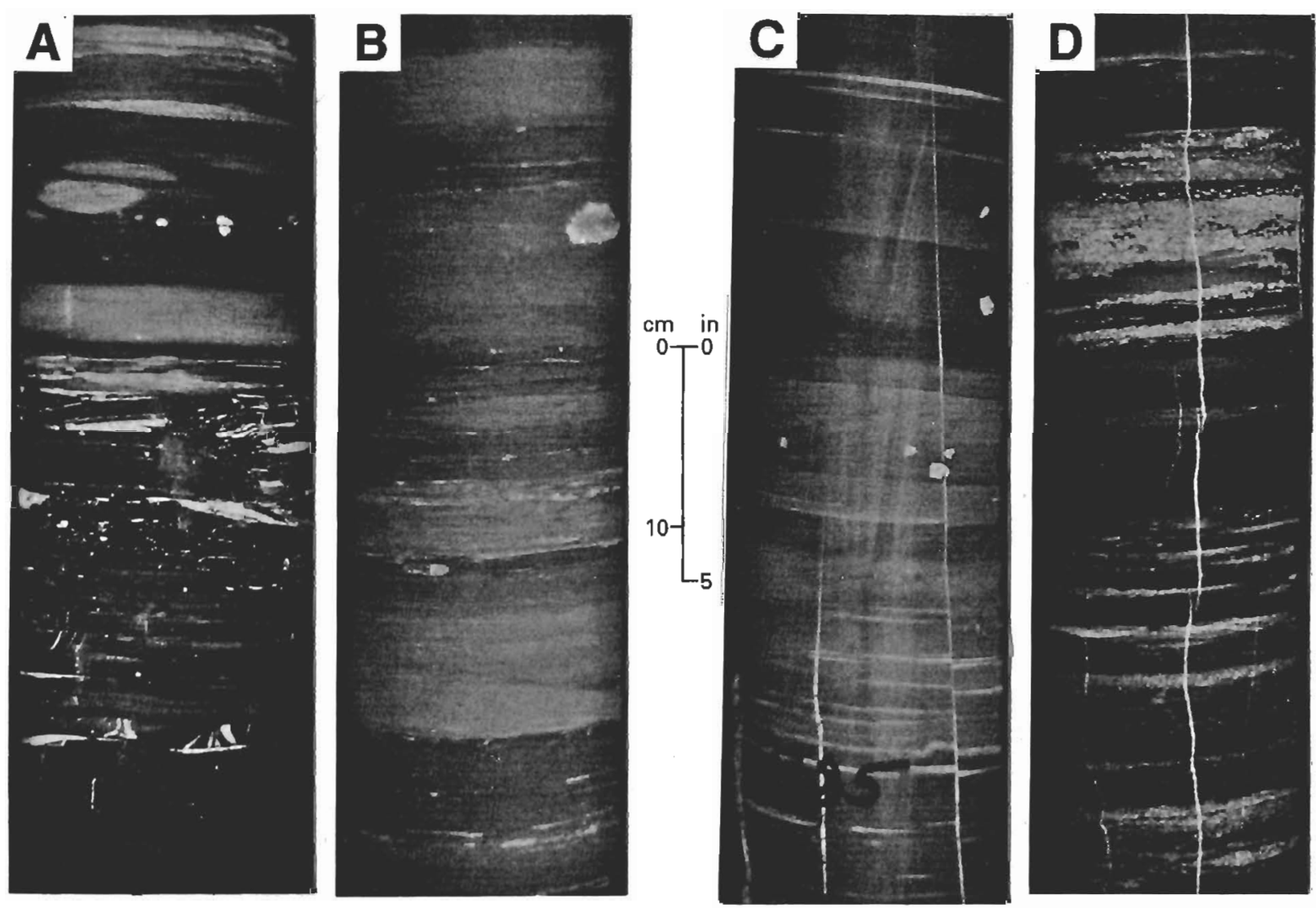

FIG. 5.-Black to dark gray, organic-rich laminites. (A) Thin, flat laminae deposited in a deep lake. White angular areas in lower two-thirds of picture are tectonic veins. Light planar and ovate areas in upper third are carbonate cement patches, and lenticular light areas at top are sand lenses. (B) Thick mudstone laminae with irregular to diffuse boundaries. Small projections of coarser material and shredded contacts are due to bedding-plane burrows. Light circular feature near top is a pyrite concretion. (C) Pinch-and-swell laminae of coarse silt- to fine sand-sized material (light), produced by oscillatory ripples, and alternating with thick mudstone laminae with diffuse boundaries. Vertical white features are tectonic veins. Light circular features are pyrite concretions. (D) Light, irregular laminae are comprised of euhedral to anhedral calcite crystals pseudomorphing former evaporites. Layers are equivalent to thick laminae with cumulate crystals or pinch-and-swell laminae composed of reworked crystals. Irregular projections are attributed to secondary crystal overgrowths after deposition. White vertical features are tectonic veins. 


\section{Gray to Red Thin Beds with Cracks}

Thin-bedded mudstone may be gray, purplish gray, and red. These mudstones are characteristically disrupted by vertical cracks filled by mudstone, siltstone, and sandstone. In some cases the cracks may preferentially contain ovate to linear features filled with sparry minerals, including analcime, albite, potassium feldspar, dolomite, and calcite. Variability in the thin beds includes (1) lenticular sandstone layers, (2) graded sandstone layers, (3) mudstone layers overlying sharp bases, (4) crystal-rich layers, and (5) muddy siltstone curls.

Lenses of well-sorted sandstone overlying scalloped erosional surfaces are interbedded with mudstone disrupted by randomly oriented tubes (Fig. 6A). The sandstone lenses were deposited by storm waves, and mudstone interbeds indicate quiescent periods with abundant burrowing organisms.

Thin beds composed mostly of mudstone may have relatively flat, shredded or diffuse boundaries (Fig. 6B), or may have irregular scour contacts. The thin beds with flat boundaries may have very thin, rhythmic sandstone lenses or sandstone filling small depressions along the contact, and commonly have abundant tube cross sections. These are interpreted as shallowwater muds in a sand-starved setting. The sandstone lenses are oscillatory ripples or storm-surge layers. The abundant tubes reflect burrowing organisms that reworked the sediment. Thin beds of mudstone with irregular scour boundaries commonly have brecciated upper contacts (Fig. 7A). Scour commonly widened the tops of polygonal cracks. Sandstone may irregularly fill scour pockets and parts of cracks. The mudstone is usually compact, with siltstone or fine sandstone partings. This mudstone association is interpreted as shallow, intermittent lake deposits that are scoured by sheetfloods during periods of desiccation.

Graded sandstone layers overlie scours with as much as $2 \mathrm{~cm}$ of relief (Fig. 6C-E). The sandstone layers may be massive or have internal inclined stratification. In some cases the scour filling also shows evidence of soft-sediment loading (Fig. 6C), whereas in others the contact is sharp and angular (Fig. 6E). Sandstone layers also exhibit climbing ripple cross-stratification in some cases (Fig. 6D). The mudstone interbeds may be similar to those associated with the sandstone lenses, or they may be more compact with silty partings. Graded sandstone layers with loaded scour bases and climbing ripple layers are both types of turbidity-flow deposits. The graded layers are most likely due to storm-wave surges, whereas the climbing ripples are from stream underflow and may represent distal deltaic deposition. Bioturbated mudstone interbeds represent quiescent periods with abundant burrowing organisms. Graded sandstone layers overlying angular scours are interpreted as shallow, intermittent lake beds deposited by sheetfloods, and the compact mudstone with siltstone partings represents the drowning of the flood waters by an expanding lake. In a few cases the climbing ripples overlie angular scour bases. These are interpreted as sheet-delta deposits that are transitional to the sheetflood deposits (Smoot and Lowenstein, 1991).

Thin beds of muddy siltstone form concave-upward lenses within compact mudstone (Fig. 6E). The siltstone may be massive or may have an internal lamination that conforms to the curl shape. The mudstone interbeds and the upper surface of the siltstone lenses are disrupted by numerous 
narrow, horizontal to vertical cracks, commonly filled with sparry minerals as described earlier. The sparry minerals also fill ovate voids within the mudstone and the muddy siltstone. These layers were deposited in shallow, intermittent lakes on a dry playa mudflat (Smoot and Olsen, 1988; Smoot, 1991). The ovate voids were vesicles formed by air trapped into mud that is intermittently water-saturated.

Pseudomorphs after bladed to equant monoclinic crystals are locally common in thin-bedded mudstones (Fig. 6G and H). The pseudomorphs consist of calcite or mixed fillings of analcime, albite, potassium feldspar, and/or dolomite. In some thin beds the crystals form radial splays that initiate on bedding planes (Fig. $6 \mathrm{H}$ ). More commonly the crystals are randomly oriented or form radial sprays within layers or, preferentially, within cracks (Fig. 6G). The size of the crystals and their habit varies in different beds, but is uniform within any bed. The crystals are interpreted as former evaporite minerals. The bedding-plane splays represent growth at the sediment brine interface as incipient crusts. Random crystals in layers are intrasediment growths in a brinesaturated mud. Where crystals are restricted to cracks, the sediment was too dry, but brine was stored in more porous material such as the crack fillings.

\section{Red to Gray Massive Beds}

Mudstones with no internal layering, or only very discontinuous internal layering, are a major part of the sedimentary record. These massive mudstones comprise the upper part of cycles and therefore the driest climatic conditions. Massive mudstones include (1) angular brecciated mudstone, (2) vesicular mudstone, (3) rounded brecciated mudstone, (4) root-disrupted mudstone, and (5) crystal-rich mudstone.

Brecciated fabrics consist of angular blocks of mudstone separated by a complex pattern of mud-filled cracks (Fig. 7). If mudstone blocks have internal layering, there is no evidence of rotation, and layers can be traced across adjacent blocks. The blocks are larger toward the base and tend to be more vertically elongated where the breccia fabric is gradational into layered mudstone. The blocks are smaller and more equant toward the top where the breccia fabric grades into other massive mudstone fabrics. Vertical, mud-filled cracks are sinuous and polygonal in plan-view, and are gradational in character to cracks disrupting the underlying bedded mudstone. Toward the top, the cracks also include horizontal components that add to the complexity of the texture. The mudstone filling the cracks may be the same color as the blocks, or, in some cases, the crack filling is red, whereas the blocks are gray or purple. The crack filling also may have ovate to linear, spar-filled voids or dispersed crystal pseudomorphs. Arcuate planes of oriented clay cut through the pattern of blocks and crack fillings in some intervals (Fig. 7C). The breccia fabric formed as a result of repeated wetting and drying of subaerially exposed lake beds by analogy to some modern playas (Smoot and Olsen, 1988; Smoot and Lowenstein, 1991). The lake muds are disrupted by polygonal cracks during wet stages, and there is little or no accumulation of sediment except in the crack fillings. New polygonal cracks form randomly over the old cracks during the subsequent desiccation stage because the entire sediment was thoroughly saturated with water. The upper part of this destructional surface is more completely disrupted by smaller secondary and tertiary desiccation cracks during prolonged 



Figure 6 

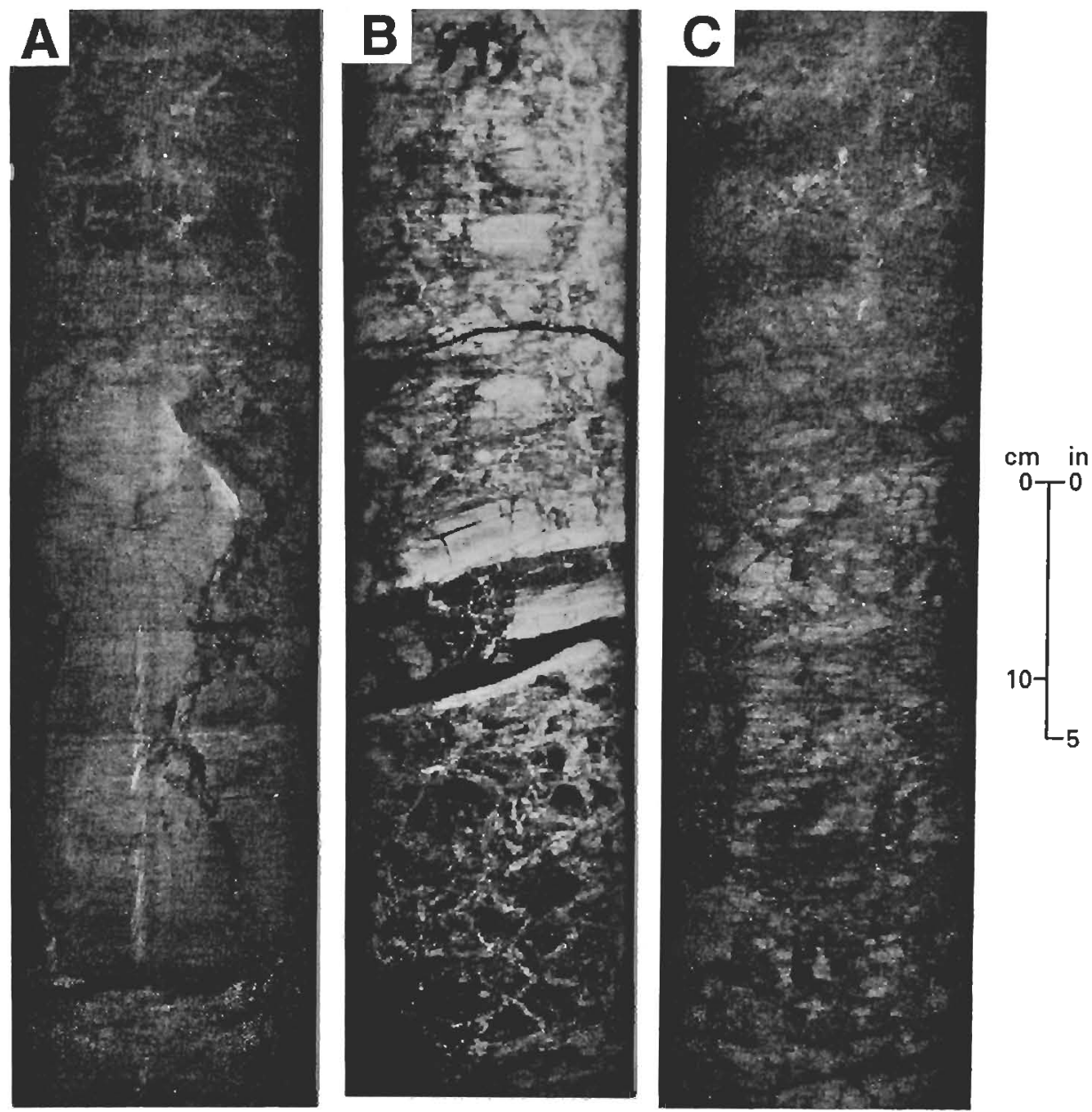

FIG. 7.-Brecciated massive mudstone. (A) Lower part is mudstone thin beds with scour bases deposited in a shallow intermittent lake. Vertical features are polygonal cracks. Note how the density and complexity of cracks increase toward the top where layering is barely visible. (B) Brecciated pattern superimposed on mudstone with graded sandstone thin beds (light). Angular clumps of mudstone are separated by a complex pattern of superimposed polygonal cracks. Note size of the clumps decreasing upward. (C) Brecciated mudstone with decreasing clump size toward top. Linear features tilted at about 45 degrees are slickenside planes formed by wetting and drying.

FIG. 6.-Gray to red thin beds with cracks. (A) Lenses of sandstone (light) alternating with mudstone. Sandstone lenses are oscillatory ripples. Vertical disruption is a polygonal crack. Small, irregular protrusions of sandstone are burrows. (B) Mudstone thin beds with irregular flat contacts. The shredded appearance and small ovate projections are burrow cross sections. Straight, vertical white features are tectonic veins. Part of a polygonal crack is visible on the left edge near the center of the picture. (C) Graded sandstone thin beds (light) with irregular bases due to loading. Sandstone layers near top are lenticular oscillatory ripples. White vertical feature is a tectonic vein. Light vertical features are polygonal cracks (particularly near the base). (D) Graded sandstone thin beds with climbing-ripple cross-lamination (light). Sandstone layers are probably turbidite underflows from a deltaic front. Note foundered ripples in mudstone layer about one-third from the top. (E) Graded sandstone thin beds (light) with irregular, angular scour bases (particularly near the base). Vertical features are polygonal cracks with complex sandstone and mudstone fillings. The sandstone layers are attributed to sheetfloods that are drowned by an expanding lake. (F) Thin beds of muddy siltstone in concave-upward polygonal lenses that are smaller upward. Vertical disruptions are polygonal cracks. White spots are cement-filled vesicles within the cracks. The siltstone layers.are interpreted as shallow, intermittent lake deposits on a dry playa mudflat. (G) Thin-bedded mudstone with abundant crystal pseudomorphs (light patches). Crystals preferentially occur in polygonal cracks (vertical features) through graded sandstone thin beds in lower half of picture. In the upper half, the crystals form radial sprays and are concentrated in a sandstone layer at the top. (H) Large crystal pseudomorphs (light) form a splay pattern in upper half. This forms by crystal growth near the sediment-water interface in standing brine. In the lower half, small anhedral to subhedral crystals preferentially fill cracks in a brecciated mudstone fabric. 
periods of subaerial exposure, thus producing the decrease of block size. Spar-filled voids are trapped air bubbles or partially filled cracks. Crystals within cracks are interpreted as former evaporites that precipitated in the more porous crack fillings rather than in the denser block matrix. The arcuate planes of aligned clays are synsedimentary slickensides that form by the expansion and contraction of the clays during wetting and drying. These are equivalent to gilgae on the sediment surface (see Wilding and Puentes, 1988).

Mudstone characterized by abundant ovate to linear voids filled with sparry minerals also has abundant narrow, jagged cracks that are filled with mud, muddy sand, and aligned clay (Fig. 8). The mudstone is typically poorly sorted and may have a blocky texture defined by cross-cutting cracks. The spar-filled voids range from nearly spherical features to narrow planes that have strongly vertical or horizontal orientation. Cracks are polygonal in plan-view and are commonly jagged or sinuous in cross section. Thin clay layers that may be hematite-rich line many cracks and voids. These mudstones are the deposits of an aggrading dry playa mudflat (Smoot and Olsen, 1988). In modern dry mudflats, the surface is dry and pavement hard and the water table is tens of feet below the surface. Complex polygonal patterns of cracks at the surface reflect the complete drying of the mud. During brief floods, the upper few centimeters of mud are watersaturated and a thin layer of sediment is introduced. Air trapped in the underlying dry mud forms bubbles in the wet mud that are preserved during desiccation. The cracks near the surface may partially collapse or flow during the wetting event which produces the sinuosity. Thin clay linings form on vesicles and open cracks by eluviation during rainstorms.

An important type of massive mudstone is gradational in character to the previously described brecciated mudstone and vesicular mudstone, but differs in that the clay blocks and clumps are well rounded and spar-filled voids are absent (Fig. 9A and B). In breccias, the mud blocks are separated by complex, cross-cutting cracks filled with sand- to granule-sized, rounded mud clumps. In the mudstones more similar to the vesicular type, the distinction between crack-filling and matrix is difficult, and the average size of rounded clumps is smaller. This texture is interpreted as a product of powdery, efflorescent salt-crust development in a saline mudflat. In modern examples (Smoot and Castens-Seidell, pers. commun.), the efflorescent crust disrupts the underlying sediment into a granular powdery mass. The evaporitic minerals forming the efflorescence round the mud granules during repeated periods of crystallization and dissolution. Where the efflorescent crust is only superficially developed on mud, the clay surface is expanded along desiccation cracks, forming a "puffy ground" surface. The granules of clay are washed or blown into the open cracks which produce the brecciated or massive fabrics with granular crack infillings. Well-developed, powdery, efflorescent crusts completely disrupt the underlying mud into sand- and silt-sized granules. There is still a suggestion of polygonal cracks on the surface which would be preserved as faint, granule-filled, vertical planes. The granular mud clumps are easily eroded, and modern saline mudflats with powdery efflorescent crusts are commonly subjected to severe deflation.

Crystal shapes that range from equant to bladed are filled with sparry minerals, including calcite, analcime, albite, potassium feldspar, dolomite, and gypsum (Fig. 9C-F). Some of the crystal shapes are demonstrably monoclinic and all are interpreted as pseudomorphs after evaporite minerals. The crystals' habits include radial sprays, isolate euhedra, and subhedral to 

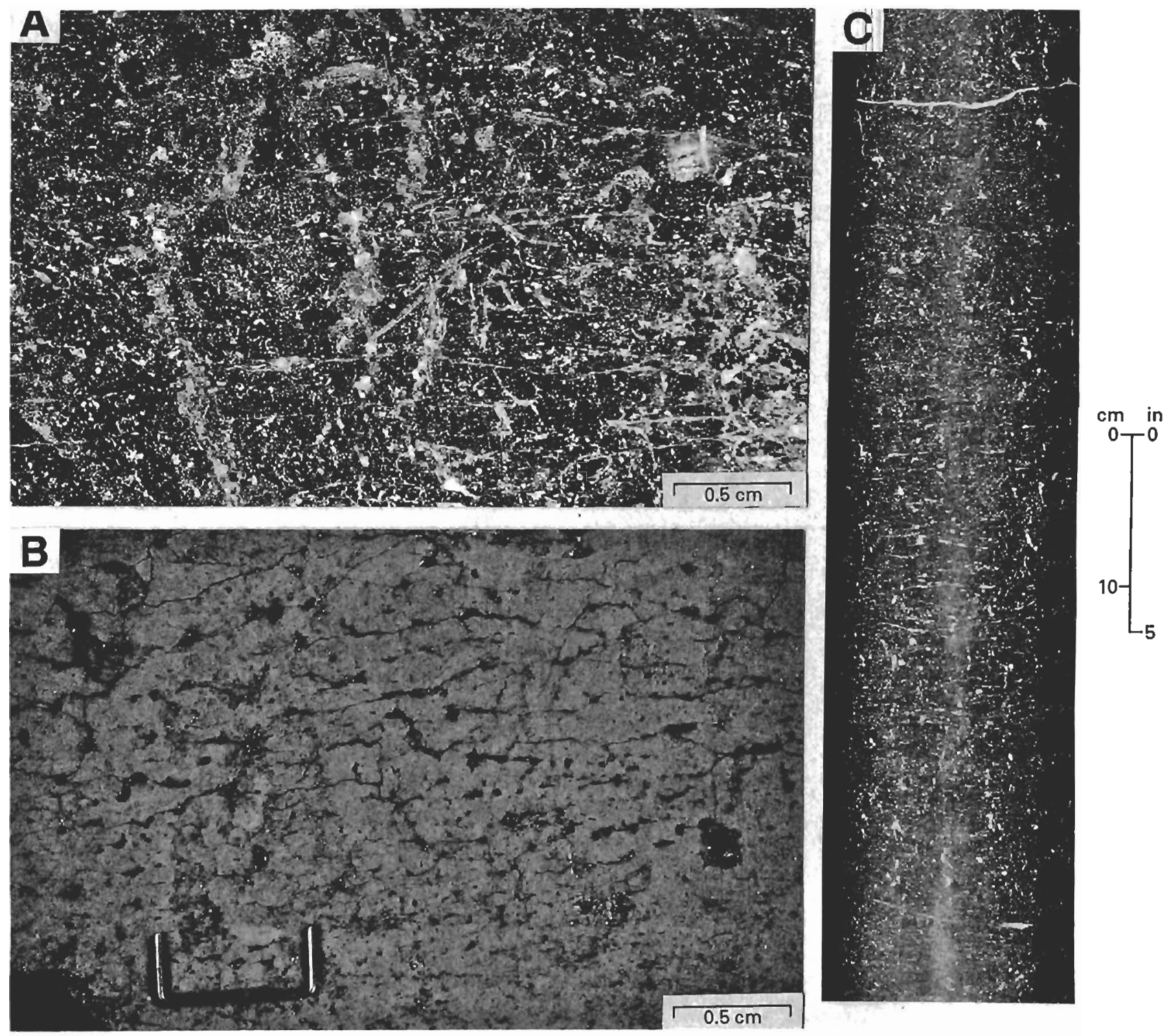

FIG. 8.-Massive mudstone with vesicular fabric. (A) Mudstone with cement-filled vesicles (white specks) and small polygonal cracks (vertical light features). Thin, horizontal cracks filled with cement (light horizontal lines) define a breccia-like pattern of mudstone clumps. (B) Polished cross section of mud from a modern dry playa mudflat showing open vesicles (dark ovate to circular features) and sheet cracks (dark horizontal lines). Sediment-filled polygonal cracks comprise vague vertical features. Note angular clumps of mud defined by the crack pattern. (C) Mudstone with cement-filled vesicles and cracks (light). Sediment-filled cracks are not easily discerned but are present. 

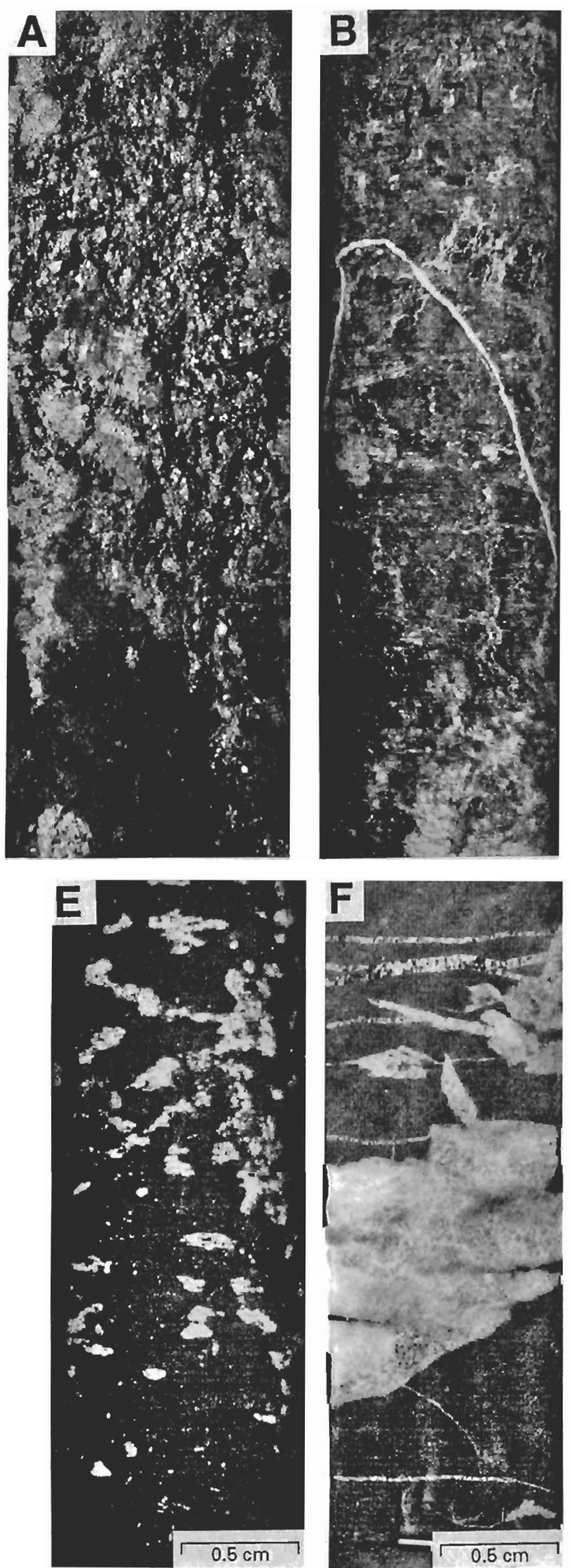
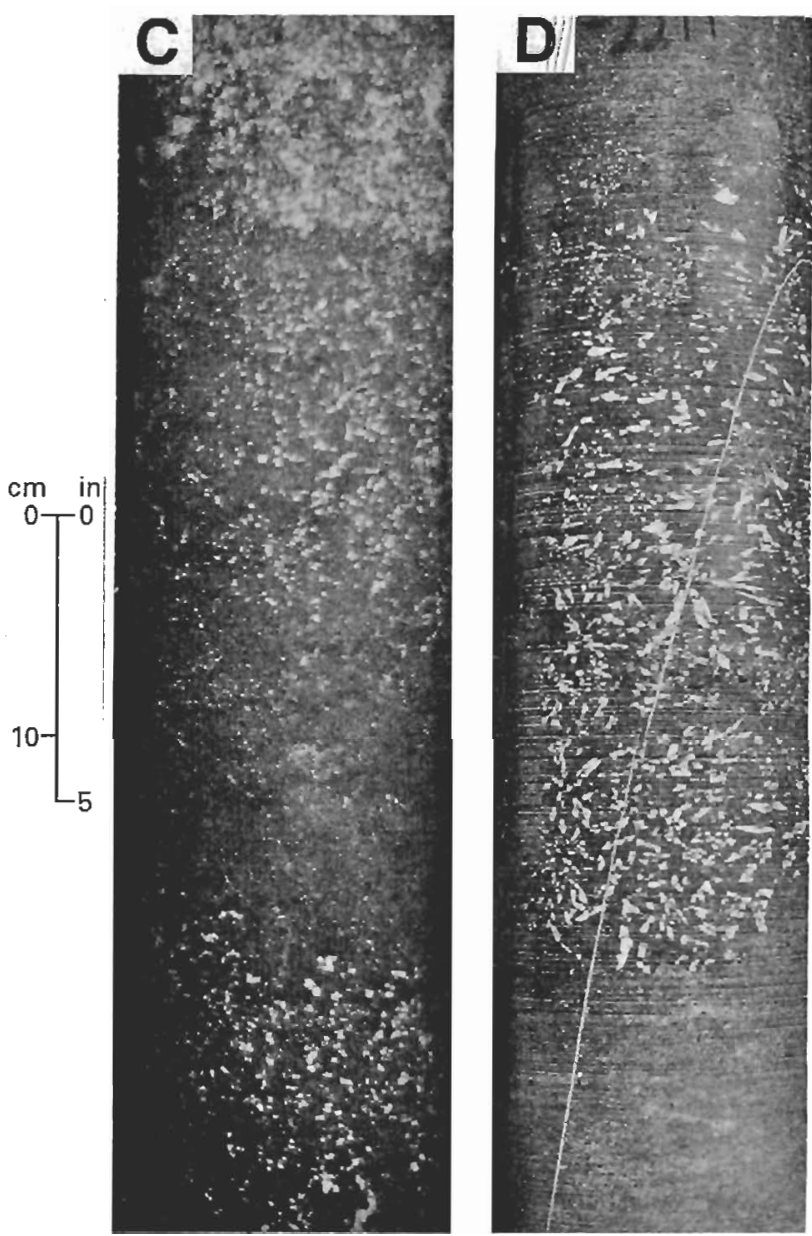

FIG. 9.-Massive mudstone with evaporite features. (A) Cross section of rounded mud clumps in a mud breccia from a modern saline mudflat with a powdery, efflorescent salt crust. Note how the sand- to granule-sized mud clumps fill vertical cracks separating larger mud clumps. (B) Mudstone with rounded sand- to granule-sized clumps filling cracks separating larger mudstone clumps near the base. This is interpreted as the product of a powdery, efflorescent salt crust. (C) Alternations of small euhedral to subhedral crystal pseudomorphs (light specks) and massive mudstone with small rounded clumps (dark structureless area). Note decrease of crystal size toward top of each zone. The crystals are actually following a polygonal crack pattern. Top of picture is a massive mudstone with rounded clumps and abundant anhedral crystal pseudomorphs. These are interpreted as vadose saline mudflat deposits. (D) Large euhedral crystal sprays (light) grading to small euhedral crystals, then massive mudstone with small rounded clumps (dark structureless area at top and at base). This is interpreted as a phreatic to vadose saline mudflat deposit. (E) Subhedral, dìscoid crystal pseudomorphs (light) preferentially following vertical tubes,(roots). Note increase of crystal size toward top. This is consistent with saline soil profiles. (F) Large pseudomorphs of discoid crystals (light) in a root-disrupted mudstone. Horizontal features are veins. 
anhedral habits. In some cases the crystals show distinct vertical successions from large euhedral crystals (mostly sprays) to small euhedral crystals to subhedral and anhedral crystals within a largely structureless mudstone matrix (Fig. 9C and D). Within this pattern the larger crystals are commonly randomly scattered, whereas the anhedral to subhedral crystals may alternate in layers that commonly follow cracks. This type of succession is consistent with that observed in modern saline mudflats, where large crystals form in the phreatic zone and progressively smaller crystals form up to the vadose zone, where layer-specific subhedral and anhedral crystals are found (Smoot and Lowenstein, 1991). Another type of crystal distribution is zones of euhedral crystals within root-disrupted mudstone or vesicular mudstone (Fig. 9E and F). The crystals within a zone are commonly the same size and shape, although they sometimes exhibit a crude upward increase in size. The crystals are most commonly randomly distributed, but may preferentially follow cracks or root structures. Large nodular to slightly discoid crystals that are now gypsum occur in some root-disrupted sandy mudstones. These types of evaporite distributions are thought to be due to soil processes. The upward increase of crystal habit or occurrence of undifferentiated crystal zones in association with roots is similar to modern saline soils (Smoot and Lowenstein, 1991). Small euhedral crystals in vesicular mudstone are consistent with modern dry mudflat occurrences, where the solutes are introduced by wind and redistributed at the surface by rainfall.

A variety of massive mudstones are disrupted by vertically and horizontally oriented, sinuous tubes of varying diameter that may be filled with sparry minerals (calcite, dolomite, albite, and potassium feldspar), silt, or clay (Fig. 10). Oriented clay lines many of the tubes, and discontinuous clay stringers in cross section are actually flattened, clay-lined tubes. Most of the tubes seen in the core are less than a millimeter in diameter, but larger, sediment-filled tubes are suggested by curved planes of oriented clay with narrow, gash-like, sparry mineral streaks parallel to the concave surface. In some cases the tubes are demonstrably branching and taper downward. In vertical sequences it is common to find larger tubes grading downward to progressively smaller tubes. In other cases the tubes are all small and almost totally horizontal. The tube fabric is interpreted as root structures. The variability in size and distribution of the tubes is thought to represent different root styles as a function of different plants and different sediment water saturation. The vertical succession of sizes is consistent with a profile of tapering roots from a bedding surface. Narrow, straight cracks filled with silt and clay are commonly associated with this fabric, as are carbonate nodules (Fig. 10C). These are interpreted as soil features, as are the clay linings that represent eluviation. In sandy mudstone, sandy layers and lenses are common, and tubes with no variability in diameter may be associated. The sandy layers are interpreted as evidence of aggrading conditions, and the tubes with no diameter changes are interpreted as burrows.

\section{CYCLE PATTERNS IN THE LOCKATONG AND PASSAIC FORMATIONS}

The sedimentary types described above are organized into five types of cycles that are gradational in character to each other. Furthermore, these cycle types have distinct stratigraphic distribution in the Newark Basin, reflecting the progressive change of climate. 

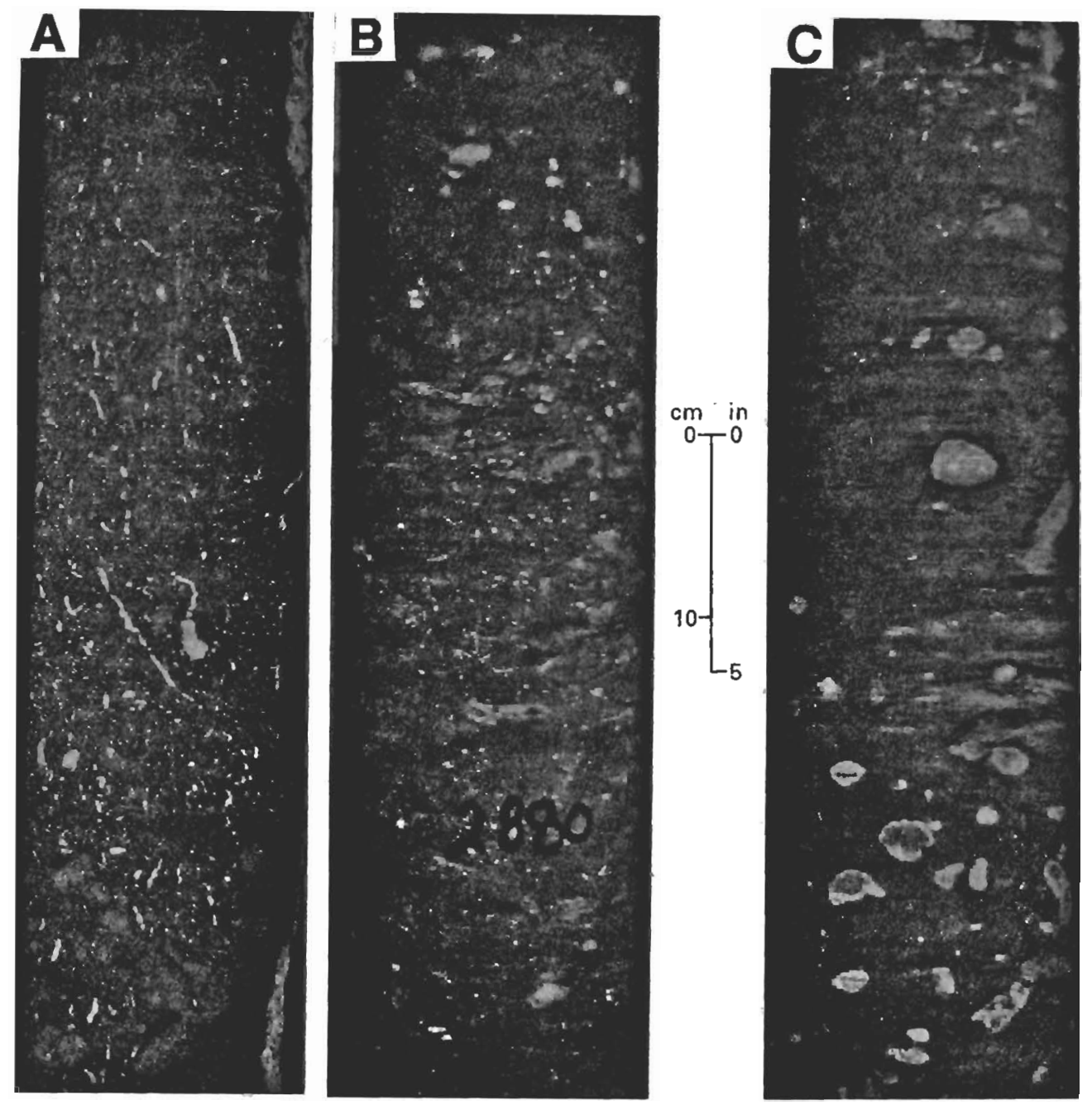

FIG. 10.-Massive mudstone with root structures. (A) Mudstone with abundant cement-filled root tubes (light). Note variety of diameters and some branching. Irregular blobs of silt near the base (dark gray) are a layer disrupted by roots and burrows. (B) Mudstone with cement-filled small roots (white) and silt-filled larger roots (light ovate to circular cross sections). Some clayfilled tubes may be burrows. (C) Mudstone with large sediment-filled roots that are not visible in photograph. Carbonate nodules (light) follow tubes and some have an elongate tube shape. The nodules are interpreted as soil carbonate (caliche). 


\section{Cycle Type I}

These cycles are dominated by thick intervals of organic-rich laminites (Figs. 11 and 12). A typical cycle begins with thin-bedded mudstone with oscillatory ripples and large mudcracks grading upward into organic-rich laminites with thick laminites and sandy laminites. Through a series of small alternations, the laminites become progressively more organic-rich and include thicker intervals of fine laminites. This trend is reversed toward the top of the cycle, and layers of crystal pseudomorphs are common in the uppermost parts of organic-rich laminites in each cycle. These also occur in the sandy thin beds, with cracks overlying the organic-rich laminites. The top of each cycle is an abrupt transition to massive mudstone with the powdery, efflorescent salt-crust fabric.

These cycles reflect development of a permanent lake that fluctuated in depth over most of the time of the Van Houten cycle. The lakes had moderate to high organic productivity, but fish fossils are only evident during the deepest stages. Early periods of intermittent subaerial exposure within a Van Houten cycle resulted in the formation of desiccation cracks but no precipitation of evaporites. However, late in the period of a Van Houten cycle, cumulate evaporites were precipitated in the shallowing lake and were partially reworked by waves. This suggests that the lake was accumulating solutes over time and that they were being stored in a lower, more saline water mass that also restricted the variety of organisms. When the lake finally dried completely, a powdery, efflorescent crust covered the old lake floor. Wind deflation of this crust removed material so that some portion of the regressive sequence was lost, accounting for the abrupt transition from lake deposits to efflorescent crust fabric. The absence of welldeveloped saline mudflat sequences associated with the efflorescent crust suggests that either the lake waters were too dilute to provide sufficient solutes or that the subaerial period was too short to establish an evaporite profile.

\section{Cycle Type II}

These cycles are similar to type I, but evaporite crystals are more abundant in thin-bedded and massive mudstones in each cycle (Figs. 13-15). The lower part of the cycle is very similar to type I, but fish fossils are less common in laminite, and the transition from organic-rich laminites into thin-bedded mudstones and brecciated mudstone commonly has crystal-crust fabrics or layerspecific, intrasediment crystal distributions. Massive mudstone overlying the thin-bedded mudstone commonly has decimeter-scale sequences of larger euhedral crystals grading to smaller euhedral crystals, grading to subhedral crystals that may be restricted to cracks, and small anhedral crystals. These sequences are progressively more dominated by anhedral crystals then powdery, efflorescent crust fabrics to the top of the cycle.

This type of cycle reflects the development of perennial lakes that are saline and the transition into shallow saline lakes and saline mudflats. The abundance of intrasediment crystals indicates a shallow, saline groundwater table over most of the time of deposition following desiccation of the lake. The variations in crystal size within the massive mudstone reflect the predominance of phreatic to vadose conditions and the gradual transition to the vadose conditions necessary for the powdery, efflorescent crust fabric. 


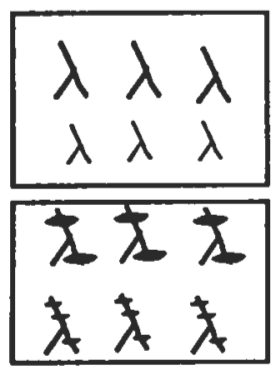

$\because 0 \circ \% \circ \% \circ$

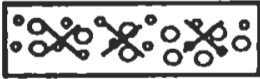

$\because 090000$

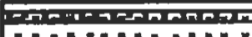

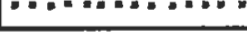

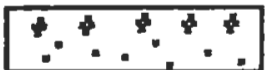

$-x+k+k$

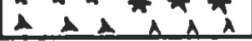

$-\infty<$

\section{$\forall \forall$
$7 \geqslant$}
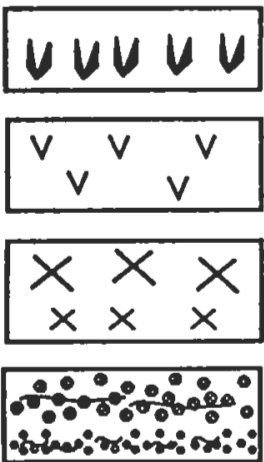

$\sim \sim \sim \sim$

\begin{tabular}{llll}
\hline 0 & $D$ & 0 & 0 \\
\hline
\end{tabular}

20
Large and

small roots

Anhedral to subhedral

crystals in roots

Efflorescent crust fabric

Efflorescent crust fabric

with mudstone breccia

Efflorescent crust fabric

with small crystals

Sand layers of small crystals

Pods or scattered small crystals

Euhedral crystals

Subhedral to anhedral crystals

Crystals following cracks

Crystal splays

Vesicular mudstone

Brecciated mudstone

Coarse and fine sand

with wispy layering

Wispy silt or very fine sand

Large burrows

Carbonate nodules

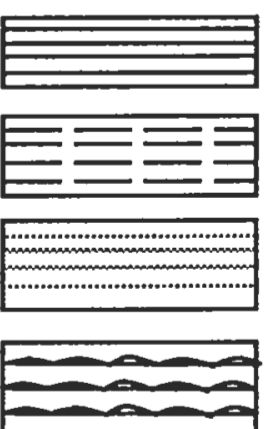

EJE=-JE=

EF--.F

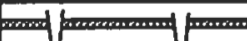

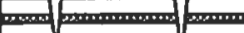

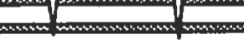
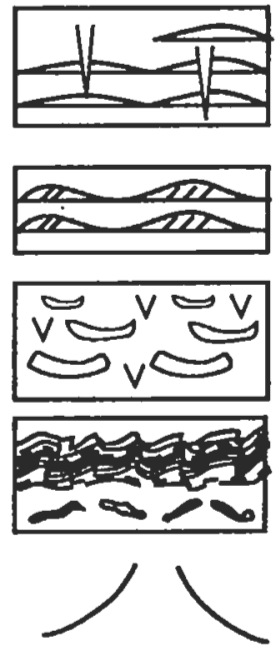

図

巫

1

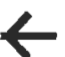

Thin, flat laminae

Thick flat laminae

Thick graded laminae

Pinch-and-swell to

lenticular laminae

Mudstone thin beds

with mudcracks

Graded silt and sand

thin beds with mudcracks

Lenticular sand

thin beds with mudcracks

Ripple cross-laminated

thin beds

Muddy silt thin beds

in polygonal curls

Deformed laminae

Slickenside planes

Gray beds

Red beds

Black beds

Van Houten cycle boundary

Upward drying sequence

Boundary of section in photos 

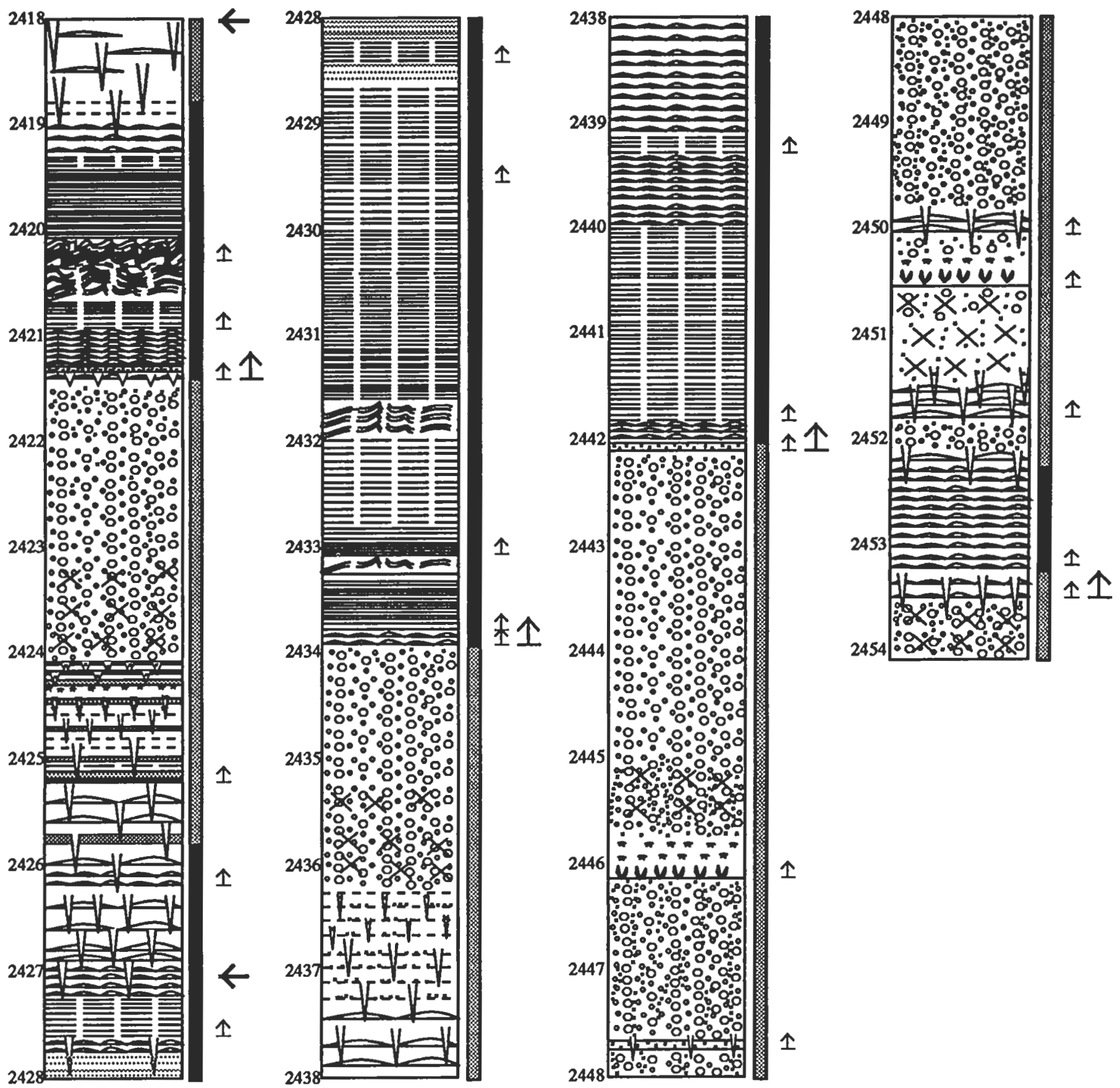

FIG. 11.-Stratigraphic section of the lower Lockatong Formation in the Nursery Road core from depths of 2418 to $2454 \mathrm{ft}$. This shows cycle type I. Deformed zones are due to tectonic slip along shale beds. 

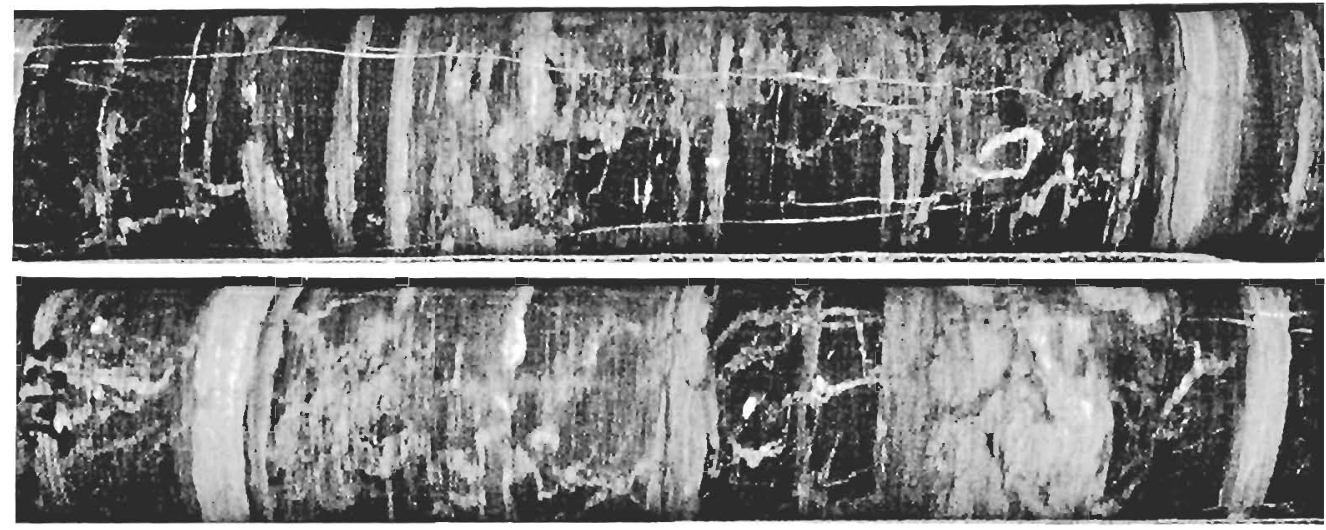

든

.马

起.

경

0

ق

$\leftrightarrows$

웅
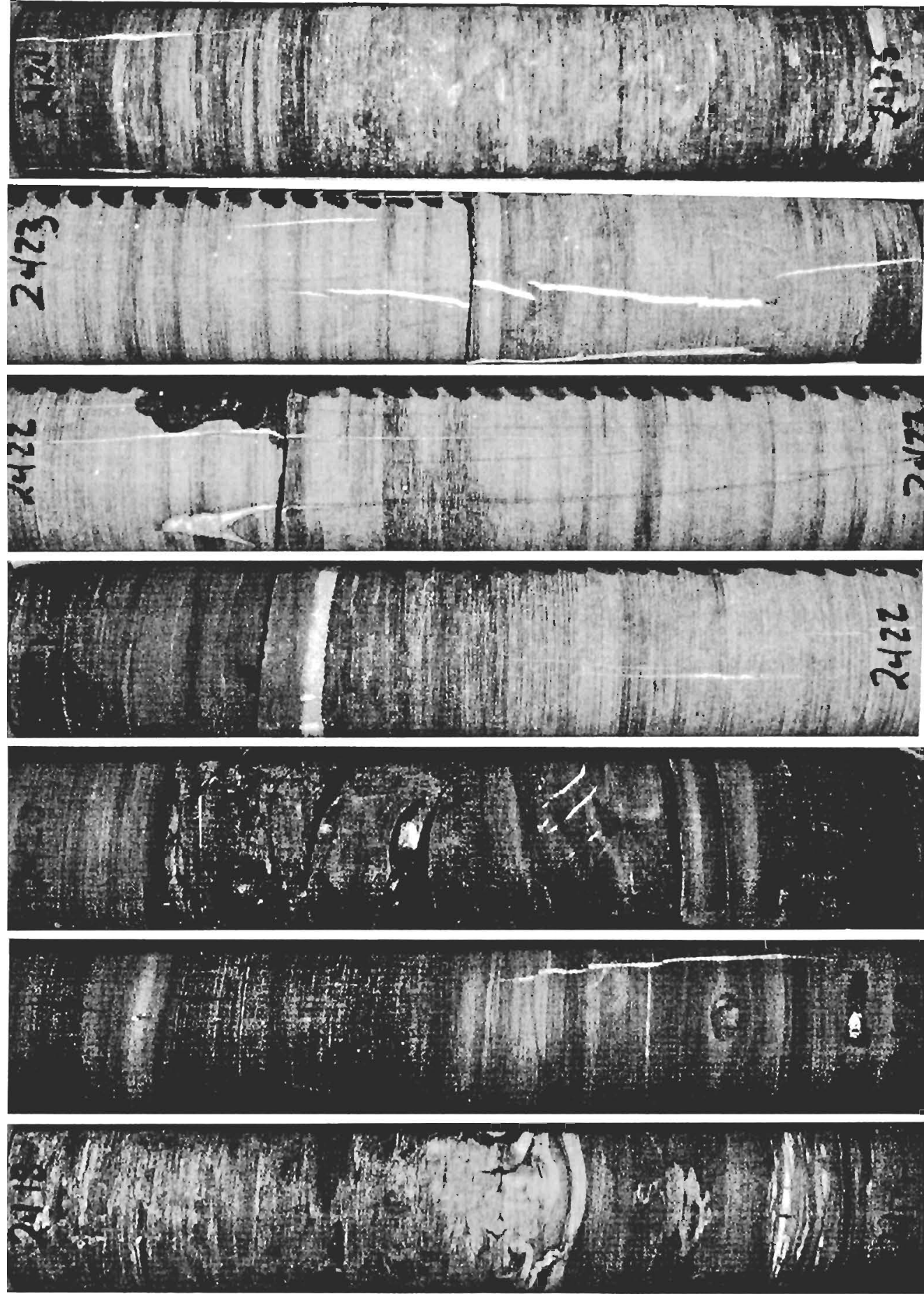

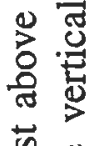

苛

\&

党

选

능 可

륨

통 연

등 웜

( )

녹 농

记 롱

드 ్ㅠㄴ

\# 8

‥

莳

$\circ$ 莳

学

离。岕

긔

怘 귱

.્ష

옴 밍 음

क幽

I $00-1$

.

点 忌

늘 苨

营㝴

응 음

《造

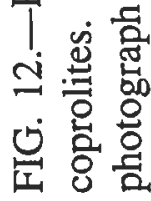




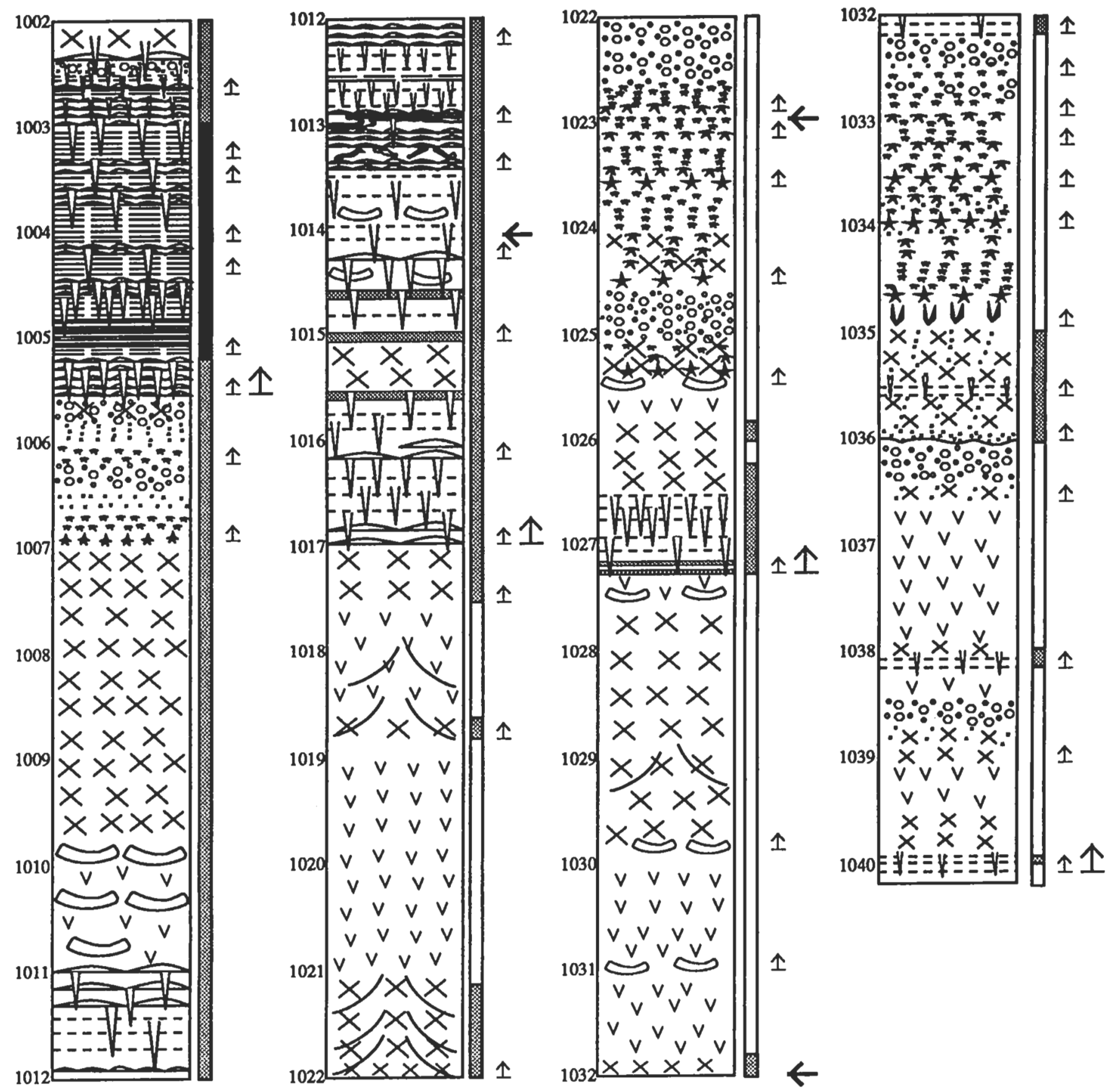

FIG. 13.-Stratigraphic section of the upper Lockatong Formation in the Nursery Road core from depths of 1002 to $1040 \mathrm{ft}$. This shows cycle types II and III. 


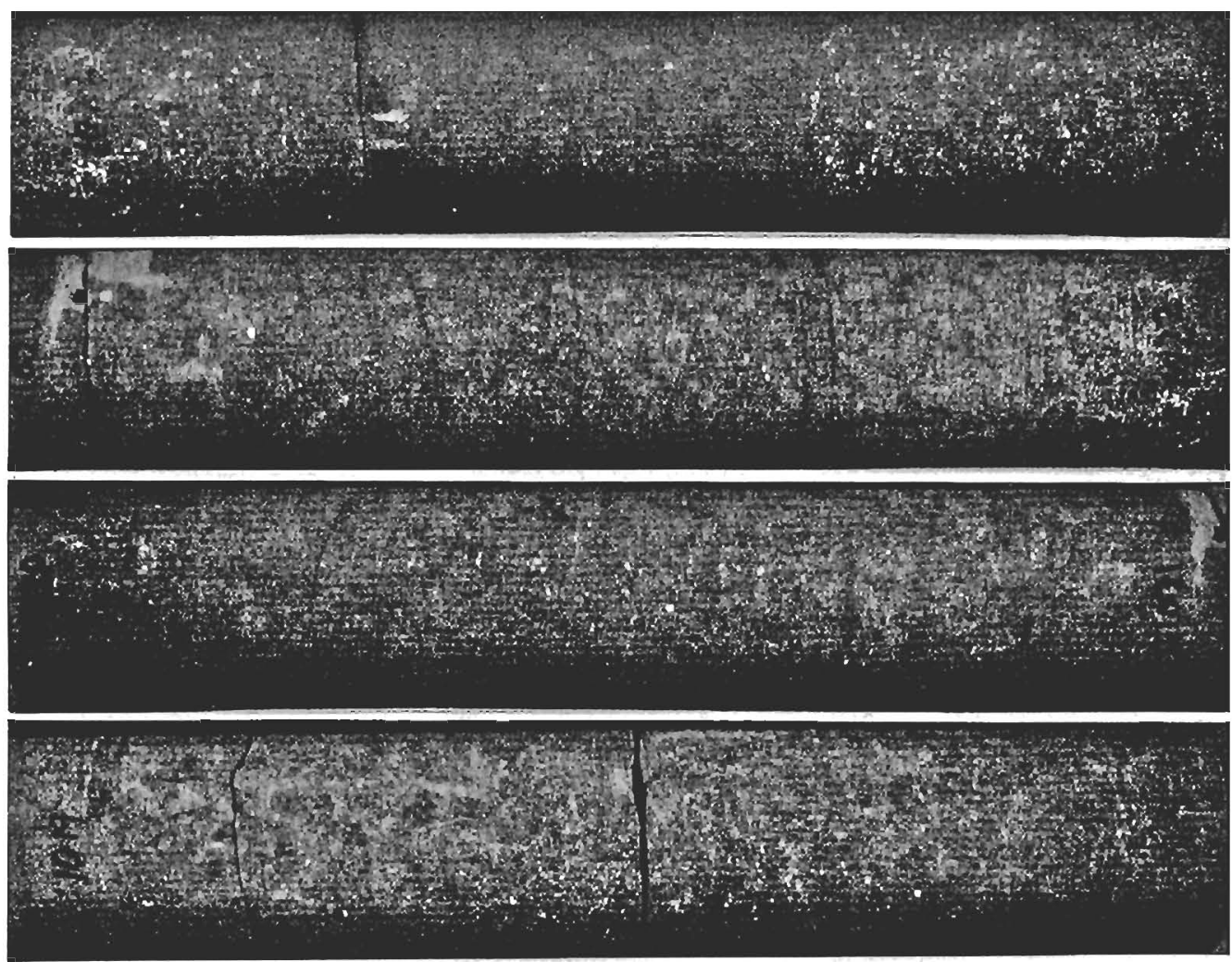

卷

ம
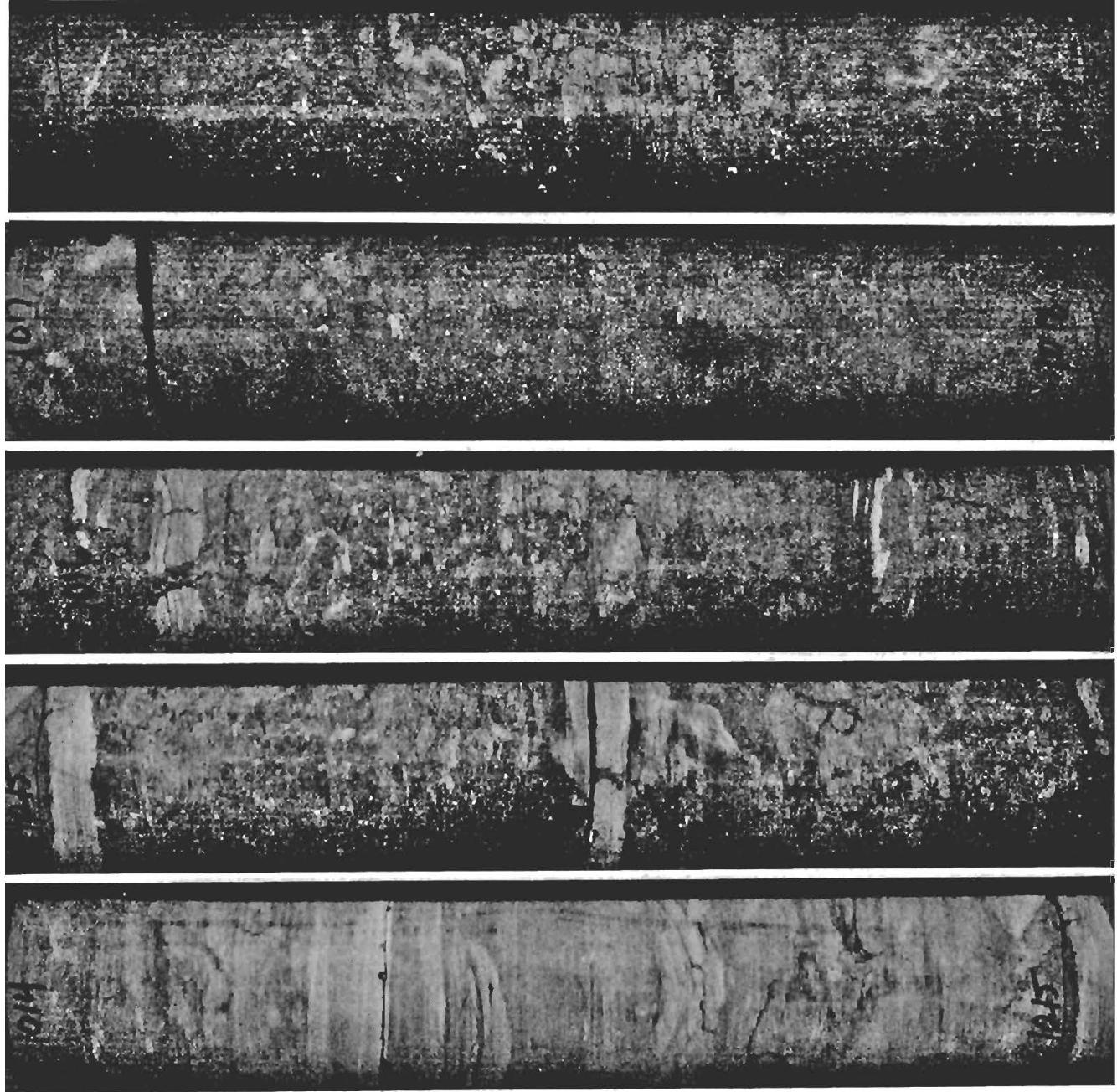

온

䒠䒕

江

.

ํํㅇ

옹

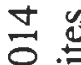

으 :

न है

志

․ㅡㄹ 능

름 है

8

㘳

돔

음 웡

๘

도웡

b0

응 胥 壳

正

1 응

$\dot{\square}$

○

州文. 

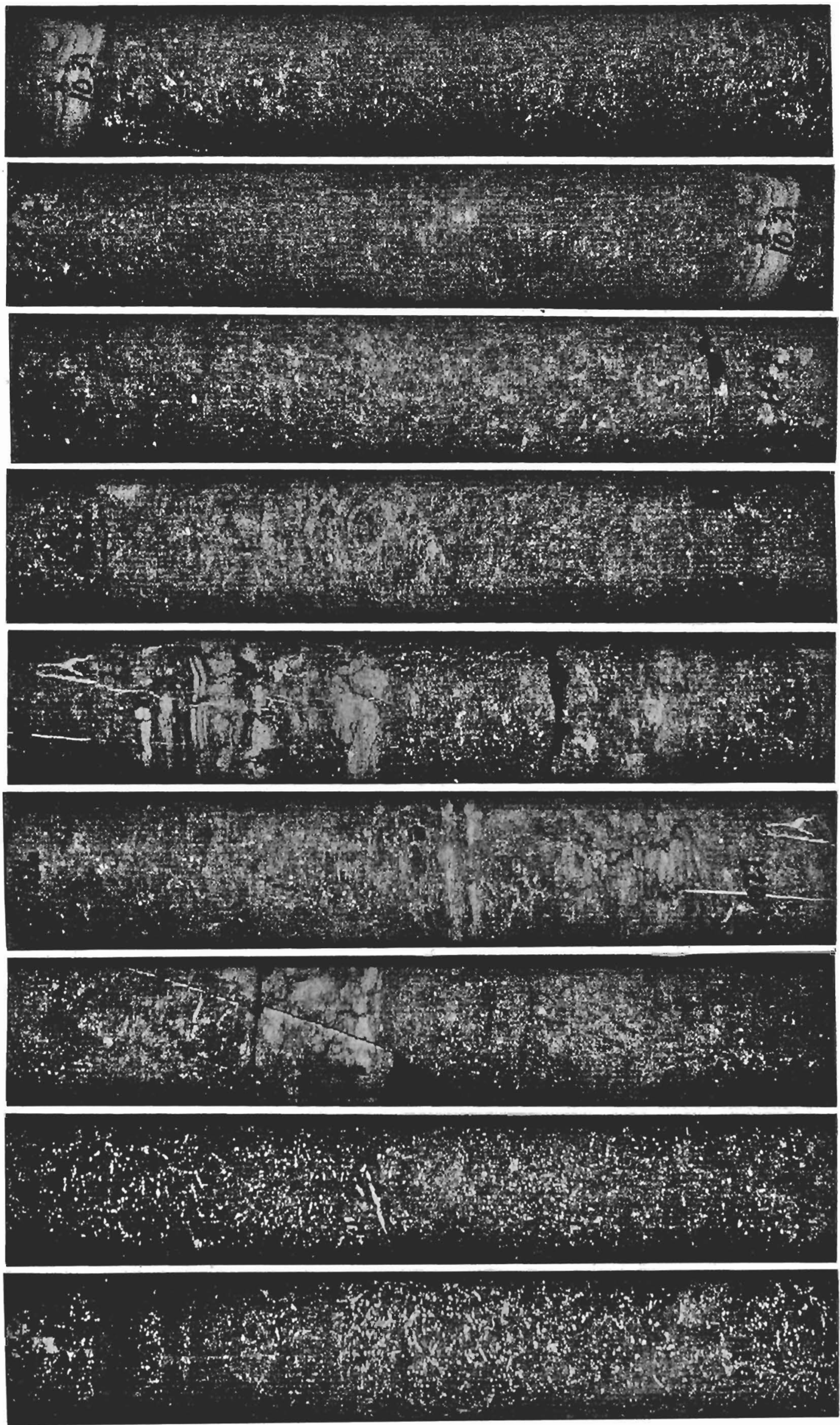

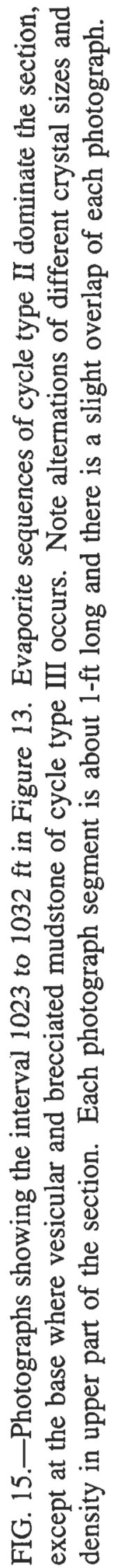




\section{Cycle Type III}

These cycles commonly start with mudcracked, thin-bedded mudstone grading upward to brecciated mudstone (Figs. 13 and 14). In some cases thin-bedded mudstone with oscillatory ripples grades up into organic-rich laminite with pinch-and-swell lamination, then back into thinbedded mudstone. Brecciated mudstone commonly contains slickenside planes and grades up into massive vesicular mudstone. Evaporite crystals are uncommon, except where organic-rich laminites are in cycles and small anhedral crystals occur in some breccia fabrics and lower parts of vesicular mudstones.

This type of cycle reflects shallow, intermittent lakes and dry playa mudflats. Perennial lakes were typically shallower and short-lived. Thin-bedded mudstones with scour layers or curled silt layers reflect very shallow lakes that were mostly dry. Brecciated mudstone reflects prolonged periods of subaerial exposure when the old lake bottom was disrupted by repeated episodes of wetting and drying. The vesicular mudstone formed in conditions where the groundwater table was well below the surface (on the scale of $10-20 \mathrm{~m}$ in modern examples). Evaporites did not form because lakes were too short-lived to accumulate solutes and the groundwater table during dry stages was too deep to be evaporated to form the minerals.

\section{Cycle Type IV}

This type of cycle is very similar to cycle type III, except that the top of each cycle is rootdisrupted mudstone (Figs. 16 and 17). The lower part of the cycle may contain thicker intervals of organic-rich laminae than type III and, with that, some evaporite minerals. The upper part of the cycle includes the vesicular mudstone grading upward into root-disrupted mudstone. In the transition, root structures are restricted to crack fillings. The root structures in these mudstones are typically of very small diameter (less than $1 \mathrm{~mm}$ ). Long, narrow cracks are common, and carbonate nodules are mostly granule-sized.

Like cycle type III, these cycles primarily reflect alternations of lakes and dry playa mudflats; however, the uppermost part of each cycle reflects a vegetated mudflat. The presence of vegetation following dry playa mudflat conditions suggests the development of a shallow, fresh, groundwater table before the next lake transgression. Whether the root structures initiate only from the lake-massive mudstone interface or the mudstone with root-disrupted fabric was aggradational is unclear. The restriction of roots to crack fillings in the transition from the dry mudflat deposits is consistent with modern vegetation that preferentially grows in cracks where moisture is captured during infrequent rainfalls. However, it is also consistent with a root following the most permeable material in the dry, hard playa mud long after burial. The carbonate nodules are interpreted as soil nodules, and the cracks are interpreted as soil prisms formed by wetting and drying at the surface. The small size of the root structures suggests that vegetation was restricted to small plants, perhaps due to limited water availability. 

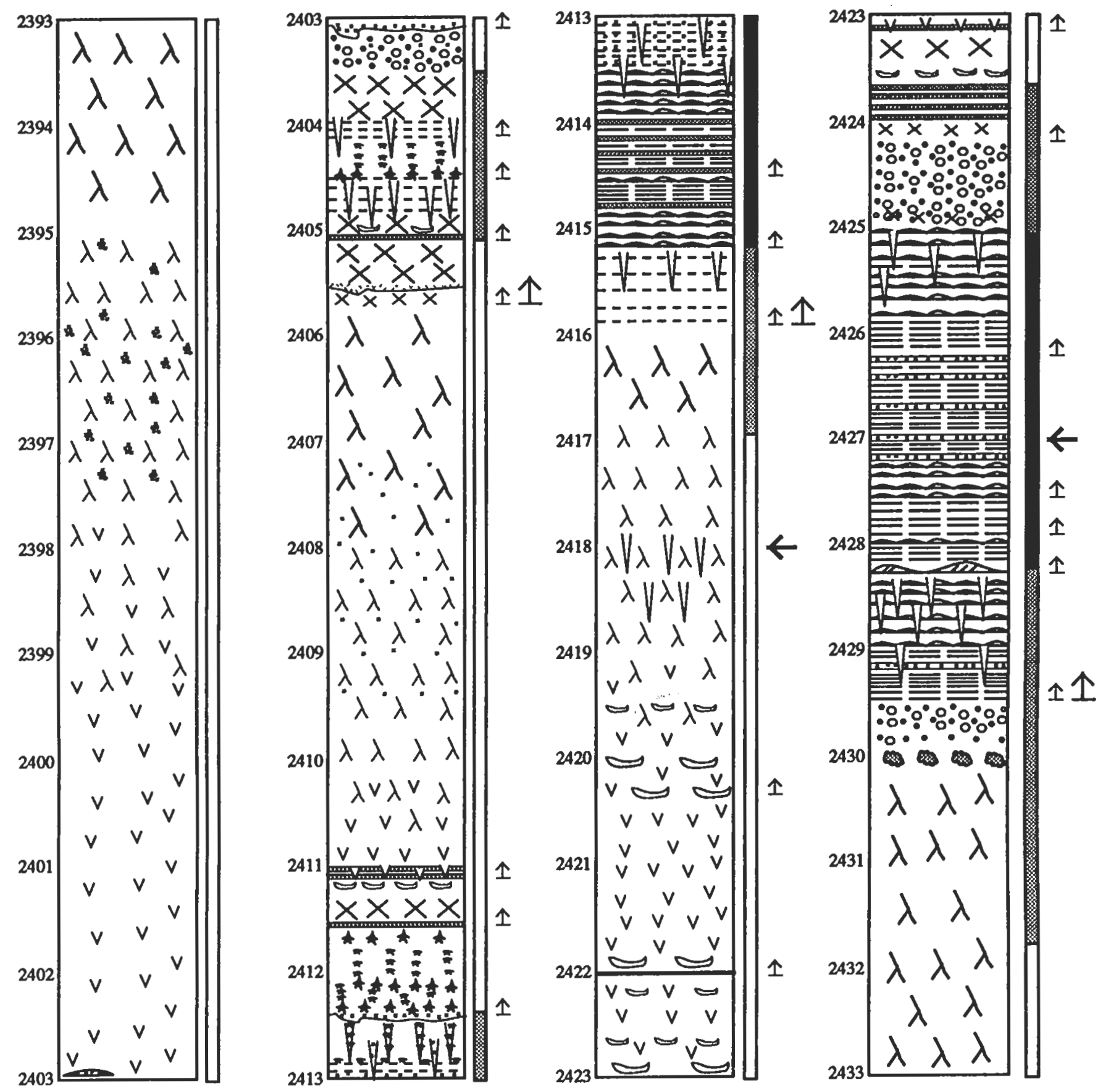

FIG. 16.-Stratigraphic section of the middle Passaic Formation in the Somerset core in the interval 2393 to $2433 \mathrm{ft}$. This shows cycle type IV and some evaporite sequences like cycle type II. 

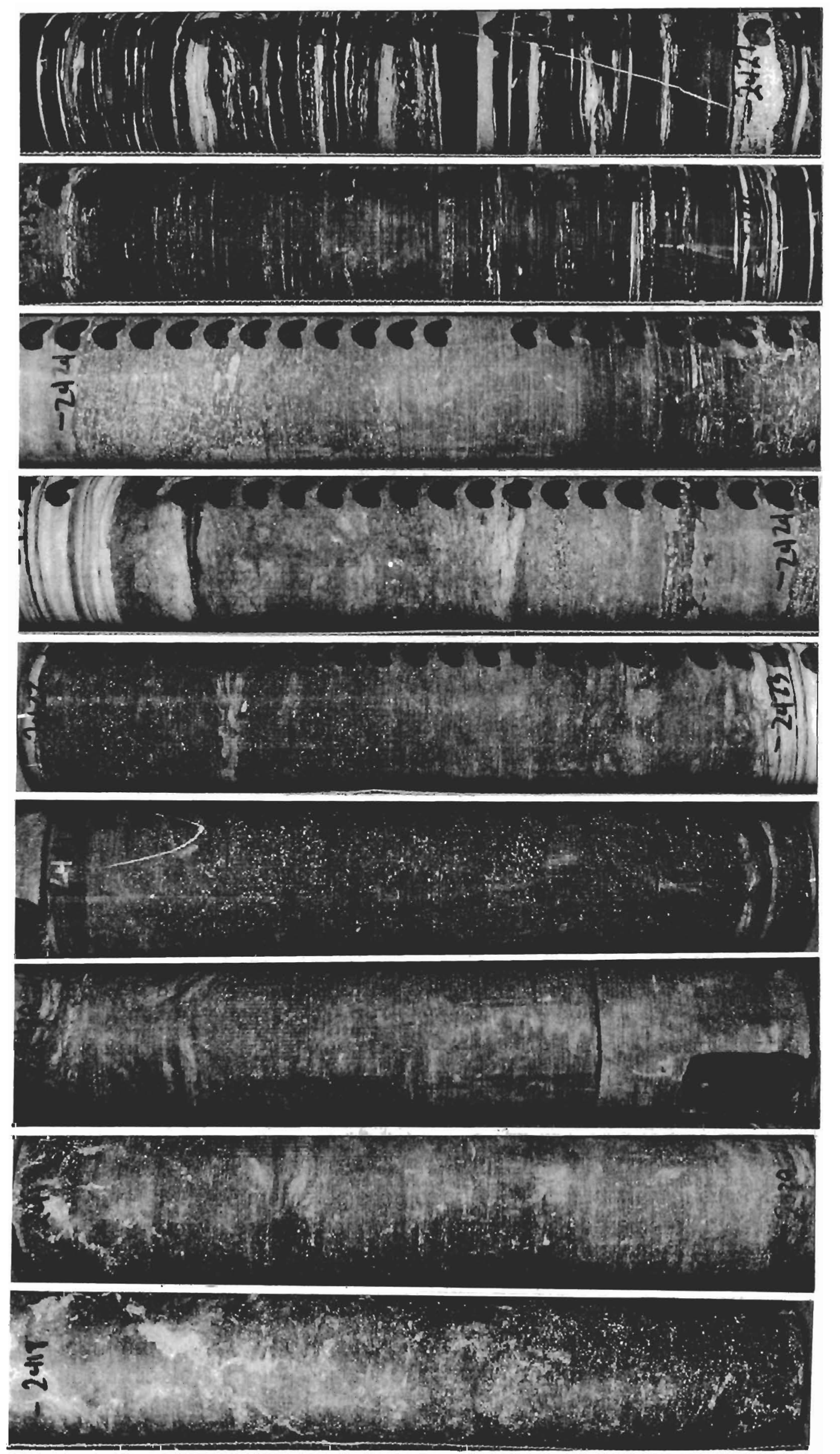

总总总 형 융

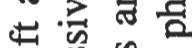
$\infty$ 음 矛 몽 용 웜 吾 荡䒘志

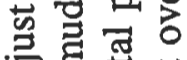
.思芯 记 总 远要 氖总总总 령 명 롱요

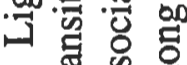
๒ 里 氙总吉

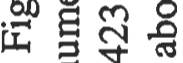

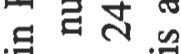

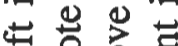
츠윰 究的范 응.己. $\infty$ 的尊 $\underset{\forall}{*}$ 究 롱 过 总吉专

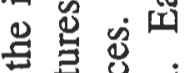
过

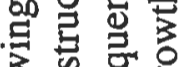
的总品 兵䔎 ๓. 起焉完

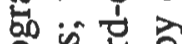
의 웡 焉完 1 중 동.马 प्⿹ 一유

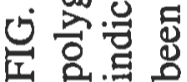




\section{Cycle Type V}

This type of cycle is characterized by alternations of sandy, thin-bedded to laminated mudstone and massive, sandy, root-disrupted mudstone (Figs. 18 and 19). Typically the thin-bedded mudstone is dominated by 0.5 to $5 \mathrm{~cm}$-thick beds of climbing ripple cross-lamination capped by silty mud. Mudcracks may be widely spaced and not visible in the core section. The finest layers are thick laminae composed of graded, very fine sand- to clay-sized sediment. The upper part of the thin-bedded interval is disrupted by closely spaced, narrow cracks and may form a brecciated fabric. This is commonly disrupted by burrows and root structures. The rootdisrupted mudstone has tubes of varying diameters, the largest being 2 to $4 \mathrm{~cm}$ in diameter. Small lenses and pockets of sand are common, and many of the tubes are filled with sand. Large nodules of carbonate and gypsum may occur near the top of a cycle and often follow large tubes or cracks. Euhedral crystal pseudomorphs also occur in some root-disrupted mudstones. These crystals are typically all the same size and morphology or show an upward increase in size.

These cycles reflect the alternation of lakes and vegetated mudflats. The lakes were mostly shallow, although some of the laminated sections may represent deeper lakes. Climbing ripple layers formed by turbidity flows from fluid underflows, as in delta toesets and foresets. The transition to subaerial deposits is partially overprinted by roots and burrows from higher surfaces. Successions of smaller to larger roots and more nodules may reflect soil profiles. The repetition of these successions within a single cycle suggests aggradation episodes punctuating soil-forming periods.

\section{STRATIGRAPHIC DISTRIBUTION OF CYCLE TYPES}

The dominant types of cycles change systematically from the base of the Lockatong Formation to the top of the Passaic Formation. In the lower third of the Lockatong Formation, cycle type I is the dominate type with a few intervals of cycle type II. Cycle types II and III dominate the upper two-thirds of the Lockatong and the lowermost Passaic formations with less common cycle type I occurrences. Cycle type IV dominates most of the lower half of the Passaic Formation with minor occurrences of cycle type II. The upper half of the Passaic Formation is almost exclusively cycle type $\mathrm{V}$.

The changes in lacustrine cycle style are interpreted as a climatic signal superimposed on the tectonically evolving basin. The lower Lockatong Formation reflects a period of high inflow into the basin, producing the thick perennial lake deposits and evaporite crusts during desiccation stages. The dearth of well-defined saline mudflat sequences suggests that the subaerial stages were short-lived so that groundwaters could not be evaporatively evolved into brines. The predominance of cycle types II and III in the upper Lockatong and lower Passaic formations indicates a transition to drier times. Desiccation stages lasted longer, allowing development of saline mudflats or dry playa mudflats during very dry periods. Cycle type IV also reflects repeated periods of dry playa mudflats, but the rooted horizons at the tops of cycles indicate increased rainfall in the basin to produce a shallow, fresh groundwater that is consistent with a change to wetter conditions. The difference here with the lower Lockatong may be the broader basin floor. During the lower Lockatong, increased rainfall would rapidly fill the narrow basin 


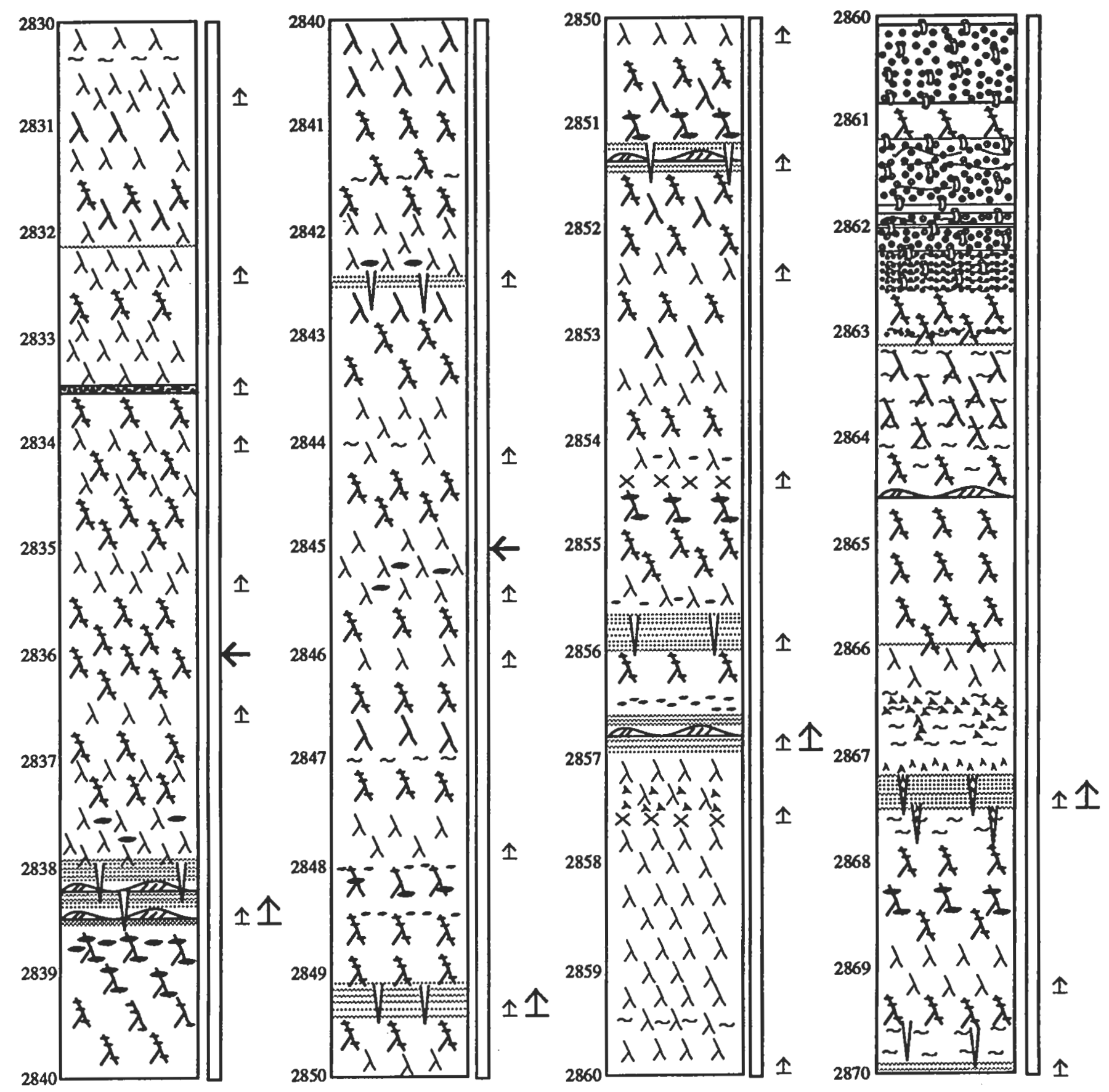

FIG. 18.-Stratigraphic section of the upper Passaic Formation in the Martinsville core in the interval 2830 to $2870 \mathrm{ft}$. This shows cycle type V. Sand layers at 2860 to $2862.5 \mathrm{ft}$ are probably eolian. 

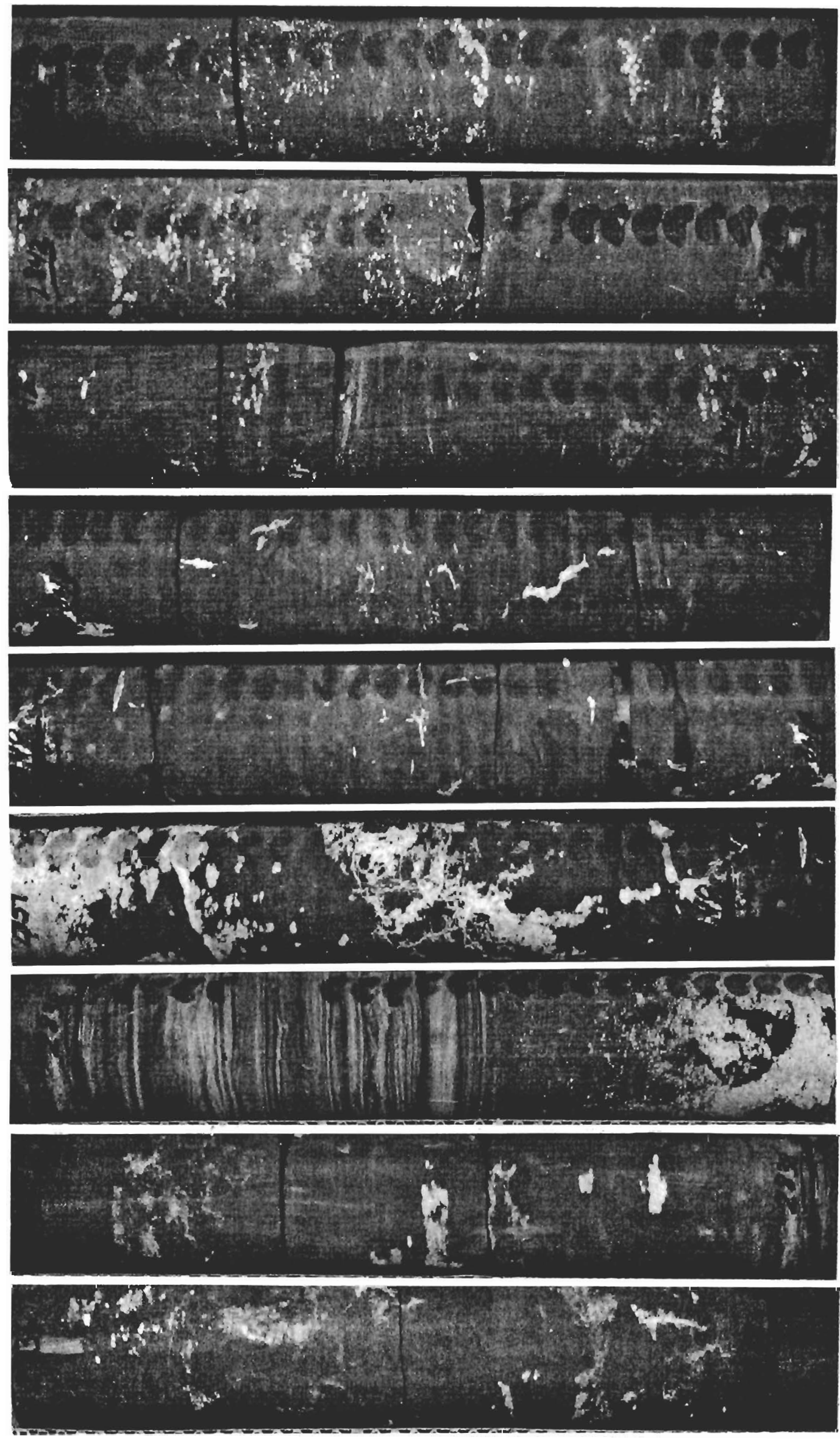

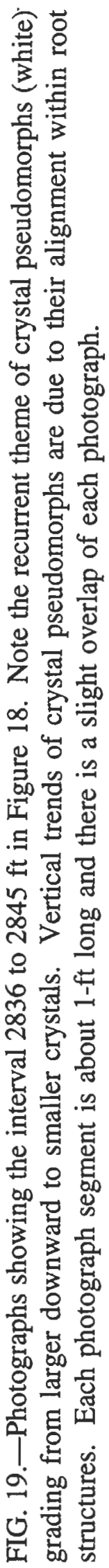


with standing water, whereas, in the broader Passaic basin floor, the same inflow may not produce significant water depths. This also tended to produce longer periods of subaerial exposure, allowing the dry mudflat and vegetated mudflat deposits to become well developed. Cycle type II occurs with all thick, organic-rich laminites in the lower Passaic indicating that a deep, perennial lake behaved the same as in the upper Lockatong when inflow was great enough. The upper Passaic Formation has no evidence of the dry playa mudflats, suggesting even wetter depositional conditions. Root-disrupted mudstone dominates the subaerial portion of cycles with vertical patterns indicative of soil profiles. The dearth of organic-rich laminites is probably an artifact of (a) the broader basin floor, producing generally shallower lakes, and (b) the oxidizing effect of the roots extending downward from the soil surfaces, producing the organic-poor laminites typical of this interval. There was still sufficient aridity in the late Passaic to produce saline soils, but the groundwater table was never as depressed as in the upper Lockatong and lower Passaic formations.

\section{IMPLICATIONS FOR PETROLEUM RESOURCES}

The lacustrine rocks of the Lockatong and Passaic formations include organic-rich units with total organic carbon as high as 8 percent. Although most of these lacustrine rocks are presently overmature (dry gas), there is abundant evidence of the migration of petroleum in oil-saturated zones and sticky inclusions within fractures. The important lessons in the Newark Basin come from the geometry of these source rocks and the controls on the distribution of potential reservoir rocks.

The distribution of organic-rich rocks in the Lockatong and Passaic formations reflects the tectonic development of the basin and climatic controls. The concentration of thicker black shales in the lower Lockatong Formation is interpreted as the result of an initially narrow basin that became broader with time. It should be noted that the surface distribution of organic-rich units in the Lockatong still covers a broader area than most modern rift basins, and the sedimentary evidence points to a low-relief basin floor. Organic-rich intervals in the Lockatong and Passaic formations are traceable over the entire basin floor, even adjacent to the faulted margin. This indicates that lakes were very deep and their surface extended beyond the present basin boundaries.

The climatic controls on the organic-rich rocks are most obvious in the cycles. The intervals of highest total organic carbon are inevitably a few tens of centimeters thick at most. Organicrich rocks are all less than a few meters thick and separated by organic-poor, subaerial mudstones that are generally over a meter thick and commonly a few meters thick. The thickness of organic-rich intervals does not increase much over the entire area of the basin, and the organicpoor partings are continuous over the entire basin floor. The climatic periodicities produced a pattern wherein the organic-rich units are grouped into 3 or 4 cycles separated by intervals of fewer organic-rich units. The rise and fall of lake level in the closed basin produced thin, sheetlike deltas that are intercalated with subaqueous and subaerial mudstones. Thick, distributary channel sandstone units did not form in this type of setting. Such deltas formed during the highest lake stands, and therefore outside the present basin boundaries, or are not preserved. The 
best potential reservoir rocks associated with the organic-rich shales are wave-reworked conglomerates in the alluvial-fan facies. These are typically thin deposits that are elongate parallel to the basin margin, but may reach thicknesses of several meters with abundant open-framework pore space.

The depositional style of the Newark Basin is comparable to that of other rift basin lacustrine sequences (see Lambiase, 1990). The major inference of the climatic relationships described here is that the occurrence of organic-rich source rocks is controlled not only by climate, but also by the tectonic history. The lateral association of facies is most strongly influenced by climate. Marginal lacustrine sequences dominated by vesicular mudstones will not be laterally equivalent to deep-water shales. However, marginal lacustrine sequences dominated by saline mudflat or rooted mudstones may be laterally equivalent to deep-water shales in the proper basinal geometry. Similarly, if the central lacustrine facies is comprised of cycles that are 3 to $5 \mathrm{~m}$ thick, as in the Newark Basin, the marginal deltaic deposits will probably be thin and sheet-like, reflecting the scale of rising and falling lake levels. If the central lacustrine facies has important components of vesicular mudstone or saline mudflat mudstones, the marginal deltaic deposits will probably be sheet deltas or stacked Gilbert-type deltas (see Smoot and Lowenstein, 1991). The use of climatic patterns in conjunction with tectonic models should provide new levels of detail in predictive models for lacustrine petroleum resources.

\section{REFERENCES}

FROELICH, A. J., AND OLSEN, P. E., 1983, Newark Supergroup, a revision of the Newark Group in eastern North America: United States Geological Survey Bulletin 1537-A, p. A55-A58.

HARMS, J. C., SOUTHARD, J. B., AND WALKER, R. G., 1982, Structures and sequences in clastic rocks, SEPM Short Course 9, Chapter 2. Bed configurations: Tulsa, Oklahoma, Society of Economic Paleontologists and Mineralogists, $55 \mathrm{p}$.

HUBERT, J. F., AND MERTZ, K. A., 1980, Eolian dune field of Late Triassic age, Fundy Basin, Nova Scotia: Geology, v. 8, p. 516-519.

1984, Eolian sandstones in the Upper TriassicLower Jurassic redbeds of the Fundy Basin: Journal of Sedimentary Petrology, v. 54, p. $798-810$.

LAMBIASE, J. J., 1990, A model for tectonic control of lacustrine stratigraphic sequences in continental rift basins, in Katz, B. J., ed., Lacustrine Basin Exploration - Case Studies and Modern Analogs: Tulsa, Oklahoma, American Association of Petroleum Geologists Memoir 50, p. 265-276.

LUTRELL, G. W., 1989, Stratigraphic nomenclature of the Newark Supergroup of eastern North America: United States Geological Survey Bulletin 1572, 136 p. 
MCLAUGHLIN, D. B., 1946, Continuity of strata in the Newark Series: Michigan Academy of Science Papers, v. 32, p. 295-303.

OLSEN, P. E., 1986, A 40-million year record of early Mesozoic orbital climate forcing: Science, v. 234, p. 842-848.

1988, Continuity of strata in the Newark and Hartford basins, in Froelich, A. J., and Robinson, Jr., G. R., eds., Studies of the Early Mesozoic Basins of the Eastern United States: United States Geological Survey Bulletin 1776, p. 6-18.

, SCHLISCHE, R. W., AND GORE, P. J. W., eds., 1989, Tectonic, depositional, and paleoecological history of Early Mesozoic rift basins, eastern North America, International Geologic Congress, Field Trip T351: Washington, D.C., American Geophysical Union, 174 p.

RATCLIFFE, N. M., AND BURTON, W. C., 1985, Fault reactivation models for origin of the Newark Basin and studies related to eastern United States seismicity, in Robinson, Jr., G. R., and Froelich, A. J., eds., Proceedings of the 2nd United States Geological Survey Workshop on Early Mesozoic Basins of the Eastern United States: United States Geological Survey Circular 946, p. 36-45.

, D'ANGELO, R. M., AND COSTAIN, J. K., 1986, Low-angle extensional faulting, reactivated mylonites, and seismic reflection geometry of the Newark Basin margin in eastern Pennsylvania: Geology, v. 14, p. 766-770.

ROBBINS, E. I., WILKES, G. P., AND TEXTORIS, D. A., 1988, Coal deposits of the Newark rift system, in Manspeizer, W., ed., Triassic-Jurassic Rifting: North America and North Africa: Amsterdam, Elsevier, p. 649-682.

SCHLISCHE, R. W., AND OLSEN, P. E., 1990, Quantitative filling model for continental extensional basins with applications to early Mesozoic rifts of eastern North America: Journal of Geology, v. 98, p. 135-155.

SMOOT, J. P., 1985, The closed basin hypothesis and its use in facies analysis of the Newark Supergroup, in Robinson, Jr., G. R., and Froelich, A. J., eds., Proceedings of the 2nd United States Geological Survey Workshop on Early Mesozoic Basins of the Eastern United States: United States Geological Survey Circular 946, p. 4-10.

1991, Sedimentary facies and depositional environments of early Mesozoic Newark Supergroup basins, eastern North America: Paleogeography, Paleoclimatology, and Paleoecology, v. 84 , p. 369-423.

AND LOWENSTEIN, T. K., 1991, Depositional environments of non-marine evaporites, in Melvin, J. L., ed., Evaporites, Petroleum and Mineral Resources: Amsterdam, Elsevier, p. 189-347. 
SMOOT, J. P., AND OLSEN, P. E., 1988, Massive mudstones in basin analysis and paleoclimatic interpretation of the Newark Supergroup, in Manspeizer, W., ed., Triassic-Jurassic Rifting: North America and North Africa: Amsterdam, Elsevier, p. 249-274.

TOLLO, R. P., AND GOTTFRIED, D., 1992, Petrochemistry of Jurassic basalt from eight cores, Newark Basin, New Jersey: Implications from the volcanic petrogenesis of the Newark Supergroup, in Puffer, J. H., and Ragland, P. C., eds., Eastern North American Mesozoic Magmatism: Geological Society of America Special Paper 268, p. 233-259.

VAN HOUTEN, F. B., 1962, Cyclic sedimentation and the origin of analcime-rich Upper Triassic Lockatong Formation, west-central New Jersey and adjacent Pennsylvania: American Journal of Science, v. 260, p. 561-576.

1964, Cyclic lacustrine sedimentation, Upper Triassic Lockatong Formation, central New Jersey and adjacent Pennsylvania, in Merriam, D. F., ed., Symposium on Cyclic Sedimentation: Kansas Geological Survey Bulletin 169, p. 497-531.

WILDING, L. P., AND PUENTES, R., eds., 1988, Vertisols: Their distribution, properties, classification, and management: College Station, Texas, Texas A\&M University Printing Center, 193 p. 